\title{
Anytime, anyplace, anywhere: kennismanagement in de platte wereld
}

Citation for published version (APA):

Harmsen, F. (2009). Anytime, anyplace, anywhere: kennismanagement in de platte wereld. Maastricht University. https://doi.org/10.26481/spe.20090417fh

Document status and date:

Published: 17/04/2009

DOI:

10.26481/spe.20090417fh

Document Version:

Publisher's PDF, also known as Version of record

\section{Please check the document version of this publication:}

- A submitted manuscript is the version of the article upon submission and before peer-review. There can be important differences between the submitted version and the official published version of record.

People interested in the research are advised to contact the author for the final version of the publication, or visit the DOI to the publisher's website.

- The final author version and the galley proof are versions of the publication after peer review.

- The final published version features the final layout of the paper including the volume, issue and page numbers.

Link to publication

\footnotetext{
General rights rights.

- You may freely distribute the URL identifying the publication in the public portal. please follow below link for the End User Agreement:

www.umlib.nl/taverne-license

Take down policy

If you believe that this document breaches copyright please contact us at:

repository@maastrichtuniversity.nl

providing details and we will investigate your claim.
}

Copyright and moral rights for the publications made accessible in the public portal are retained by the authors and/or other copyright owners and it is a condition of accessing publications that users recognise and abide by the legal requirements associated with these

- Users may download and print one copy of any publication from the public portal for the purpose of private study or research.

- You may not further distribute the material or use it for any profit-making activity or commercial gain

If the publication is distributed under the terms of Article $25 \mathrm{fa}$ of the Dutch Copyright Act, indicated by the "Taverne" license above, 


\section{Maastricht University}

\section{Dr. Frank Harmsen}

Faculty Humanities \& Sciences

Anytime, Anyplace, Anywhere:

Kennismanagement in de platte wereld

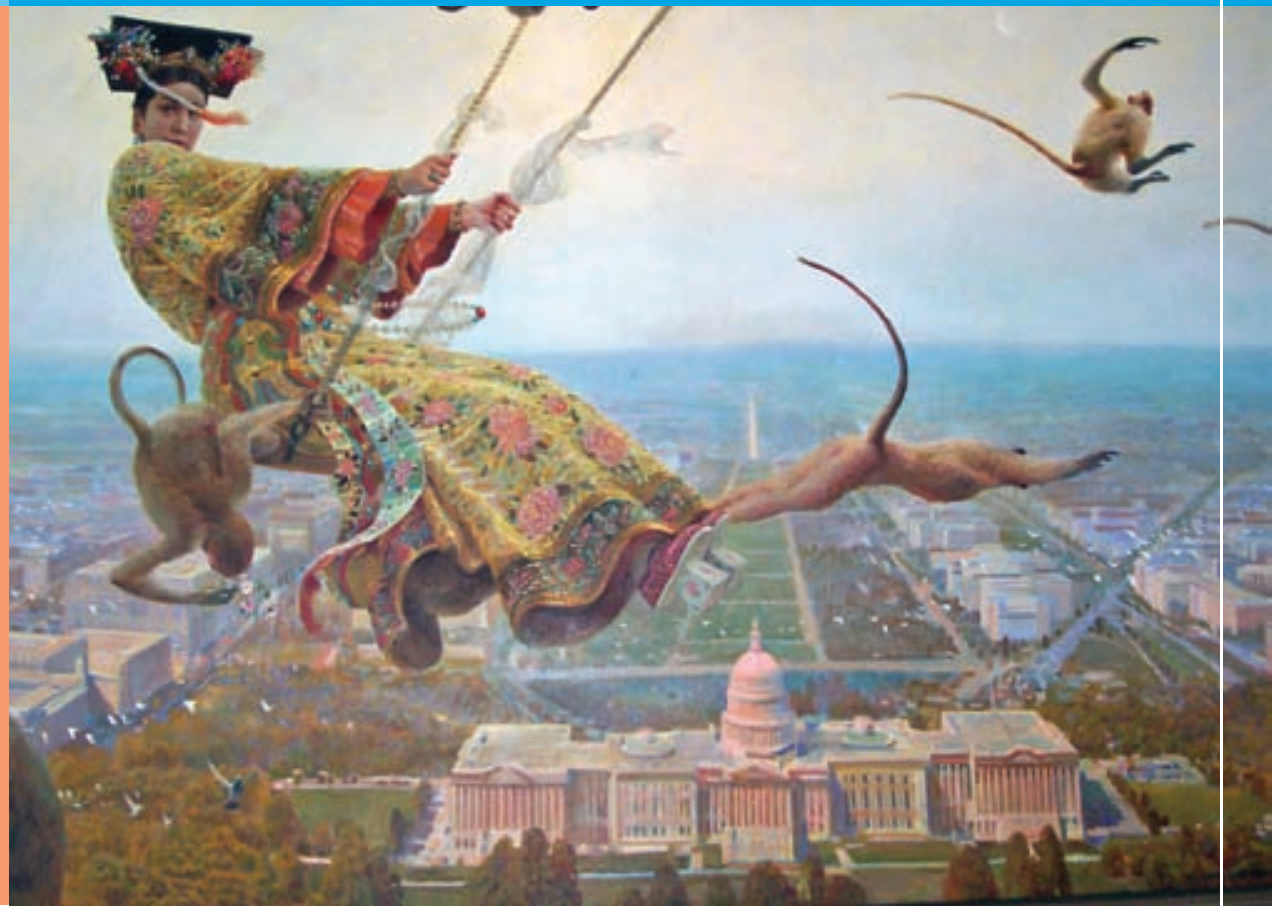


Anytime, Anyplace, Anywhere:

Kennismanagement in de platte wereld 


\section{Colofon}

Design and print: Océ Business Services, Maastricht

ISBN: 978-90-5681-310-9

NUR: 980

Alle rechten voorbehouden. Niets uit deze uitgave mag worden verveelvoudigd, opgeslagen in een geautomatiseerd gegevensbestand of openbaar gemaakt worden, zonder voorafgaande schriftelijke toestemming van de auteur of uitgever. 


\section{Anytime, Anyplace, Anywhere: Kennismanagement in de platte wereld}

Rede

In vrije vorm uitgesproken bij de aanvaarding van het ambt van bijzonder hoogleraar Knowledge Management of Global Work aan de faculty Humanities \& Sciences van de Universiteit Maastricht

Op vrijdag 17 a pril 2009

door

Dr. Frank Harmsen 
Inhoudsopgave 
Mijnheer de RectorMagnificus, beste collega's, lieve vrienden en familieleden en overige gewaardeerde toehoorders,

Acht jaar geleden was ik als consultant ingehuurd door een grote Bank, verantwoordelijk voor de verbetering van het systeemontwikkelproces het proces waarmee de Bank haar informatiesystemen maakt. We deden dat in een project, en dat project was onderdeel van een groter geheel, een verbeterprogramma.

In een ander deel van datzelfde programma werd toen besloten om een Indiaas bedrijf in te huren. Dat bedrijf moest ervoor zorg dragen, dat de kwaliteit van de gebouwde informatiesystemen altijd op een bepaald, min of meer voorspelbaar, niveau zou liggen. Daarnaast zouden de projecten met behulp waarvan de informatiesystemen worden gebouwd, ook veel voorspelbaarder moeten worden.

Ik herinner me nog goed de scepsis die heerste bij de Nederlandse partijen in het programma. Ja, we wisten dat Indiërs goed zijn en dat ze inmiddels een indrukwekkende IT-industrie hadden opgebouwd. Ja, we wisten dat ze daarbij gebruik maakten van kwaliteitsmodellen die Westerse bedrijven niet of nauwelijks onder de knie konden krijgen. Maar we waren er ook van overtuigd, dat de Indiase cultuur niet strookte met de Nederlandse. Dat het voor hen heel lastig zou zijn om dat wat in India heel normaal is, ook in Nederland over het voetlicht te krijgen. En last but not least: hoe moesten die Indiërs de kennis vergaren die nodig is om de IT-afdeling van een Westerse bank te begrijpen? We maakten ons grote zorgen. En onderhuids sluimerde toch ook nog een beetje het gevoel, dat India "maar" een derdewereldland was dat door óns van ontwikkelingshulp moest worden voorzien - niet andersom!

Toen de Indiërs er eenmaal waren, moesten we op bijna alle fronten onze mening herzien. In het algemeen waren het zeer deskundige consultants, die inderdaad wel wat last hadden van de specifieke Nederlandse cultuur, maar die ook door hun ervaring respect afdwongen. Ik weet niet zeker of ze ons en ons land begrepen. Wat ik wel zeker weet, is dat ze hun kennis op een zeer gedegen wijze met ons, de Nederlanders, deelden. Omdat iedereen zijn best deed om er een succes van te maken, slaagde uiteindelijk het team van Nederlanders en Indiërs erin om haar missie te voltooien. Het programma was een daverend succes. 
Een tweede eye-opener kreeg ik toen ik 3 jaar geleden in Mumbai was. Net als veel andere Aziatische megasteden is ook Mumbai een toon beeld van dynamiek, het bruist. Het lijkt gevuld te zijn met miljoenen zeer gretige mensen die, als ze er toe in staat worden gesteld, maar één ding willen: carrière maken en heel veel geld verdienen. Ik werkte daar in één van de gebouwen van Capgemini op een kantoortuin. lets verderop in dat kantoor was een project aan de gang voor het UWV, de Nederlandse uitkeringsinstantie. Tot mijn verbazing hoorde ik af en toe mijn Indiase collega's, die in dat project werkten, Nederlandse woorden in de mond nemen:woorden als "uitkering", "ziekteverzuim", "uitkeringsgerechtigde”. Die verbazing werd nog groter toen ik ze bezig zag met de ontwerpen voor de software die zij ontwikkelden: die waren in het Nederlands! Toen ik ze vroeg hoe ze dat voor elkaar kregen, antwoordden mijn collega's: "Simpel. We leren de belangrijkste termen en wat woordjes Nederlands erbij en als we er niet uitkomen, chatten we met onze collega's in Nederland en vragen we om verduidelijking. Soms hebben we een videoconferentie om de voortgang te bespreken en ook dan vragen we nog wel eens om verduidelijking". Toen ik ze vroeg of ze ook een beeld hadden bij bijvoorbeeld het begrip "uitkeringsgerechtigde" aarzelden ze. Voor een Indiër is het erg moeilijk om nee te zeggen.

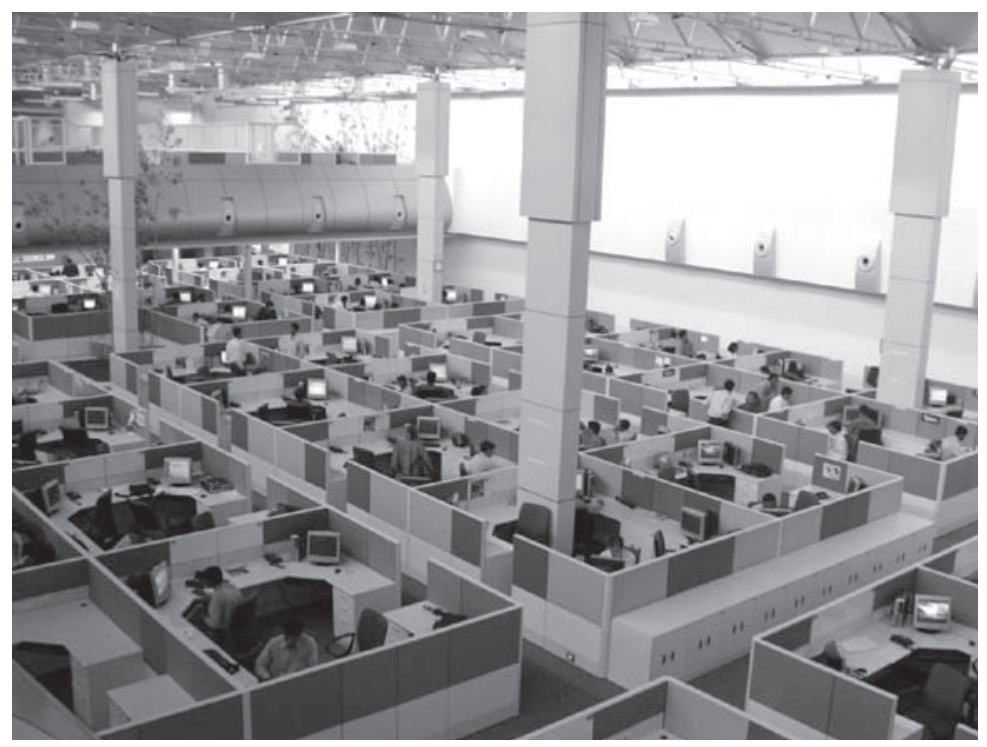

Figuur 1 Binnen in één van de Capgemini gebouwen in Mumbai 
Ondanks, of misschien wel mede dankzij, de crises die onze aarde, en India specifiek, momenteel teisteren, zijn we in een andere wereld aanbeland. In zijn beroemde boek "The World is Flat" (Friedmann, 2005) beschrijft Thomas Friedmann, één van de columnisten van de New York Times, hoe de wereld, in zijn woorden, steeds "platter" wordt. In het begin van het boek beschrijft ook hij zijn Aha Erlebnis aan de hand van het verslag van een studiereis die hij in Bangalore maakte. Hij bezocht daar IT-bedrijven en hij was zeer onder de indruk. De uitdrukking "The World is Flat" ontleent hij aan de metafoor van de aarde als speelveld. Dat speelveld wordt steeds vlakker, wordt als het ware geëgaliseerd. Landen als India, China en Vietnam kunnen als nooit tevoren meedingen naar wereldwijd uitbesteed werk in wat we de "kennissector" noemen. De laatste jaren zien we op dit vlak ook een geweldige opkomst van Oost-Europa, Zuid-Amerika en, gelukkig, óók delen van Afrika.

Friedmann noemt in zijn boek een aantal "flatteners": gebeurtenissen of feiten die er aan hebben bijgedragen dat het globale speelveld steeds egaler wordt. Belangrijke "flatteners" zijn de val van de Berlijnse Muur, de beschikbaarheid van goedkope glasvezelnetwerken, maar ook de beschikbaarheid van zoekprogramma's als Google. Kunt u zich nog het pre-google tijdperk voorstellen? Weet $u$ nog, dat als $u$ wat wilde weten in de encyclopedie keek, of naar de bibliotheek ging? Toen ik promovendus was, en dat is nog maar 13 jaar geleden, ging ik naar de universiteitsbibliotheek om de wetenschappelijke artikelen die ik nodig had voor mijn promotie-onderzoek te lenen. Van collega's kreeg ik wel tips, ook al wel via mail, maar als ik een bepaald onderwerp nader wilde bestuderen betekende dat vooral veel sjouwen met boeken, eventueel kopiëren van artikelen, via de literatuurlijst van artikelen verder zoeken en verder via conferenties en workshops kennis uitwisselen. Tegenwoordig gaat dat allemaal via internet en zijn vele zoekmachines. We zijn beland in een tijdperk waarin informatie en kennis alom aanwezig en terstond oproepbaar zijn. Wellicht is er sprake van te véél informatie, waardoor we nu niet alleen in een kredietcrisis, een klimaatcrisis, een voedselcrisis en een milieucrisis verzeild zijn geraakt, maar ook in een informatiecrisis. Die crisis kenmerkt zich door een grote mate van informatievervuiling (Stol, 2009) - en net als de andere grote crises van dit moment is ook deze crisis door de mens veroorzaakt, en kan wellicht ook door de mens worden opgelost. Tegelijkertijd neemt de behoefte aan kennis, en dat is wat anders dan informatie (zie hoofdstuk 2), toe. Die kennis moet overal altijd beschikbaar zijn volgens het Martini-principe: "Anytime, Anyplace, 
Anywhere". Een bedrijf als Capgemini, dat bijna 100.000 werknemers heeft in zo'n 40 landen, waarvan $40 \%$ werkzaam in zogenaamde lagelonelanden, móet simpelweg aan dit principe voldoen, omdat het anders niet meer concurrerend is. Het ervoor zorgen dat kennis overal altijd voorhanden is, is daarom belangrijk, en verdient dan ook een leerstoel. Ik ben dan ook erg blij dat het College van Bestuur van de Universiteit Maastricht deze leerstoel, waarvoor ik nu mijn oratie uitspreek, heeft ingesteld.

Het wereldwijd uitwisselen van kennis is niets nieuws en kreeg ruim 150 jaar geleden een geweldige zet. Toen werd de "Great Atlantic Cable", de eerste trans-Atlantische telegraafkabel, op de bodem van de oceaan gelegd. Voor het eerst konden twee overzeese continenten "direct" met elkaar communiceren. Na een aantal tests stuurde koningin Victoria op 16 augustus 1858 het eerste officiële telegram van Europa naar de VS. Het had 99 woorden en duurde toch nog een halve dag om het te verzenden. Aan weerszijden van de oceaan was deze gebeurtenis aanleiding tot enorme feestvreugde. In New York werd zelfs zoveel vuurwerk afgestoken, dat het dak van het stadhuis afbrandde. En dat terwijl de meest verstuurde zin via de kabel was "Kunt u dat herhalen?", omdat de signalen zo zwak waren. De vreugde was overigens van korte duur: na een maand en 400 berichten viel de kabel uit en door de Amerikaanse Burgeroorlog duurde het nog tot 1866 voordat er een nieuwe, robuustere kabel op de bodem van de Atlantische Oceaan lag (Schrijver, 2008). Toen kon de globalisering pas goed beginnen!

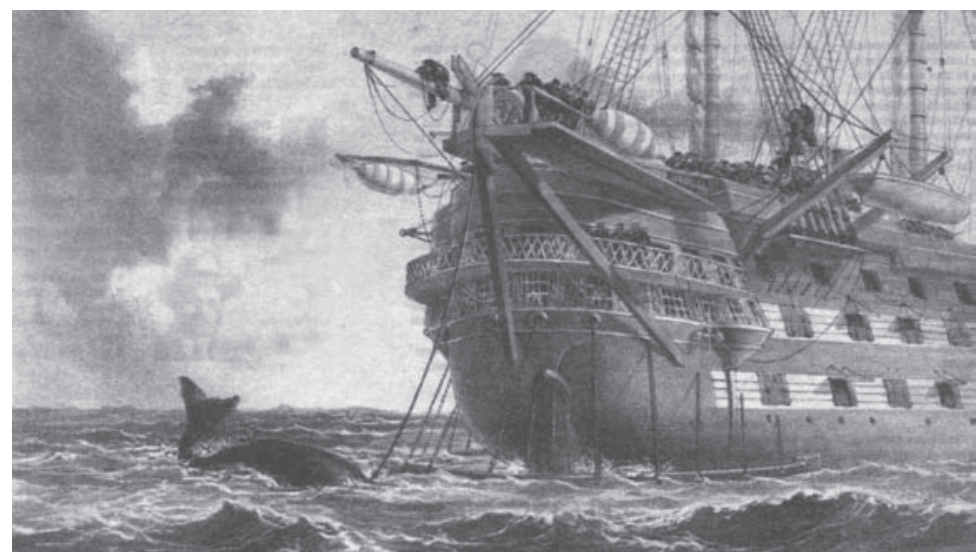

Figuur 2 Het schip dat de kabel legde 
In 2009 is het globaliseren van werk niets bijzonders meer. Van een stuk werk worden verschillende delen op verschillende contintenten uitgevoerd. Preciezer geformuleerd: het werk wordt dáár uitgevoerd, waar het het beste kan worden gedaan - anytime, anyplace, anywhere. In mijn eerste ervaring met de Indiase collega's was het werk nog niet over de aardbol verspreid: de Indiërs kwamen naar Nederland, in plaats van dat het werk naar India toe ging. Toch was ook mijn ervaring bij die bank een voorbeeld van het platter worden van de wereld: tien jaar daarvoor had niemand het in zijn hoofd gehaald om Indiase consultants in te schakelen, simpelweg omdat de Indiërs toen nog nauwelijks een IT-industrie hadden. Ook de bijzondere omstandigheid dat twee redelijk verschillende culturen met elkaar samenwerken is een voorbeeld van globalisering.

Deze ontwikkeling is om minimaal 2 redenen nieuw. Reden 1 is dat het om kenniswerk gaat. Werk dat je met je hoofd, en niet met je handen doet. Reden 2 is, dat het speelveld ook werkelijk egaal wordt en dat landen gelijkwaardig aan elkaar worden.

In de wereld is het natuurlijk al eeuwen zo, dat werk op verschillende plekken wordt verricht. In het Romeinse rijk kwamen de amforen uit Zuid-Italië en Griekenland en het glas uit Egypte en de Levant, omdat op die locaties de omstandigheden het beste waren om die producten te maken. De transporttijd die dat met zich meebracht woog daar niet tegenop. In de tijd van de ontdekkingsreizen en de Nederlandse Gouden Eeuw kwam de globalisering pas goed op gang. De VOC was een mooi voorbeeld van een onderneming die zeer profiteerde van de producten die de Oost, in het bijzonder natuurlijk Nederlands Indië, voortbracht. Vanaf de 19 e eeuw zien we de opkomst van de multinationale onderneming en de industrialisatie, die, zeker in de zoe eeuw, volledig geglobaliseerd werd: Industrieën gingen zich daar vestigen, waar de omstandigheden het best waren. Dat betekende in veel gevallen een trektocht over de wereld. Eén van de mooiste voorbeelden hiervan is de textielindustrie, die de laatste paar honderd jaar een reeks verhuizingen over de wereld heeft gemaakt, bijvoorbeeld van Europa naar Noord-Amerika en vervolgens via Mexico, India, de Filippijnen en Indonesië naar Afrika.

Toch waren dit soort vormen van globalisering anders. Het ging immers bijna altijd om concrete, dus tastbare, producten die verspreid over de wereld werden gemaakt. Daarnaast was het speelveld bijna nooit vlak. 
Landen werden gekoloniseerd, mensen werden gedwongen tot slavernij of anders uitgebuit - er was geen sprake van gelijkwaardigheid.

In mijn onderzoek ga ik me richten op kenniswerk dat over de wereld is verspreid. Meer specifiek richt ik me op werk in de informatietechnologie, de IT. Dit is bij uitstek een sector waarin niet tastbare (abstracte) producten worden opgeleverd of beheerd en waarbij kennis, en vooral overdracht van kennis, een grote rol speelt. Het gaat immers vrijwel altijd om hoogwaardig, innovatief werk, waarvoor veel kennis is vereist. Die kennis moet worden gevonden, gecreëerd, vergaard, gedeeld, opgeslagen, beheerd, vermeerderd en verwijderd - ofwel, er moet aan kennismanagement worden gedaan!

De IT-sector is een mooi voorbeeld van een bedrijfstak die de afgelopen jaren in hoog tempo is geglobaliseerd. Juist omdat het gaat om nietconcrete producten lijkt dit ook makkelijk te kunnen. Immers, als je software ontwikkelt hoef je nauwelijks fysieke producten over de aardbol te transporteren - het gaat allemaal in bits en bytes over netwerkverbindingen. Het is een abstracte wereld, het lijkt dus ook een abstracte globalisering.

Dat blijkt echter niet helemaal waar te zijn, en wel om twee redenen:

- De eerste reden is, dat informatietechnologie vrijwel altijd gebruikt wordt ter ondersteuning van processen en producten in de "echte wereld". Die processen en producten kunnen wel degelijk concreet zijn en worden steeds geavanceerder. Denk maar eens aan de voorraad van een willekeurige auto-importeur, laten we zeggen BMW: hij wil de voorraad BMW's op een bepaalde optimale grootte hebben en houden en daarvoor zijn logistieke softwarepakketten beschikbaar. Die software mag dan abstract zijn, de BMW's op zijn parkeerplaats en het importeren en verkopen van die BMW's is wel degelijk concreet. Het maakt hem heel veel uit of hij met een voorraad blijft zitten of dat hij zo optimaal mogelijk auto's kan inen verkopen. Met die processen en producten is ook altijd kennis gemoeid, die vaak ook nog eens van locale aard is. Denk maar eens aan het voorbeeld van het UWV dat ik in het begin gebruikte en het begrip "uitkeringsgerechtigde".

- De tweede reden is, dat er ook kennis nodig is voor het werk zelf. Informatiesystemen worden in het algemeen projectmatig ontwikkeld, aan de hand van een systeemontwikkelmethode. Als 
een systeem-ontwikkelproject verspreid over de wereld wordt uitgevoerd, is het wel zo handig dat er één methode wordt gebruikt. Die methode fungeert als gemeenschappelijke taal voor het project. Er is dus op alle projectlocaties kennis nodig van die methode.

Een vereenvoudigde weergave van zo'n methode is te vinden in Figuur 3. Elk van de activiteiten kan op een andere plek in de wereld worden uitgevoerd. Zo kunnen bijvoorbeeld de analyse en het ontwerp in Heerlen en Amsterdam worden uitgevoerd, de bouw en een deel van de test in Hyderabad, een ander deel van de test in Amsterdam en de overdracht in Heerlen. Uiteraard zijn ook andere combinaties mogelijk. Het is belangrijk dat elk van de projectleden weet, wat hij moet doen en hoe zijn werk zich verhoudt tot het werk van anderen.

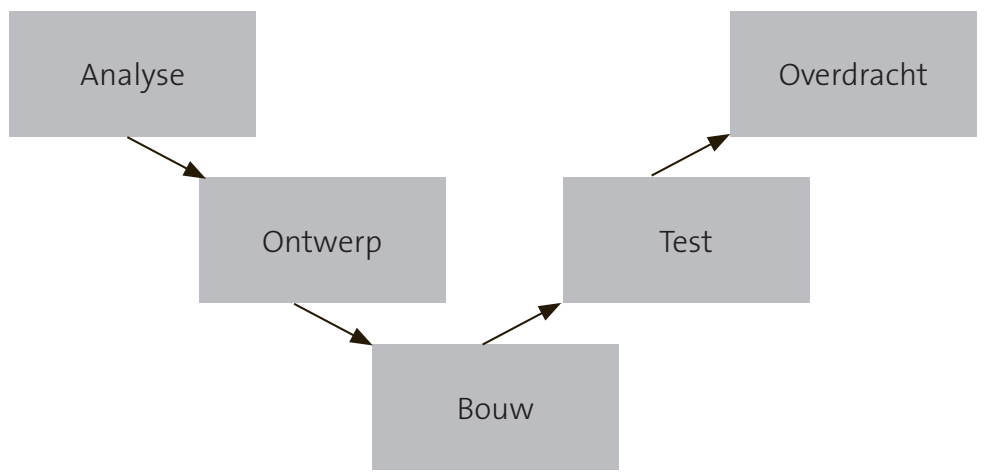

Figuur 3 Voorbeeld van een systeemontwikkelmethode

In deze rede zal ik een aantal onderwerpen behandelen met betrekking tot het wereldwijd verspreiden van IT werk en dan specifiek de rol die het managen van kennis daarin speelt. Achtereenvolgens ga ik in op de centrale begrippen wereldwijd verspreid werk, kennis en kennismanagement. Daarna ga ik in op mijn onderzoeksvraag: Hoe zou je er voor kunnen zorgen dat die kennis op een optimale wijze wordt gemanaged? 


\section{Wereldwijd verspreid werk}

Wereldwijd verspreid werk is er in soorten en maten. In jargon wordt voor het uitvoeren van werk de term sourcing gebruikt. Sourcing is het overnemen van functies en/of werknemers en/of faciliteiten van een organisatie, de klant. De leverancier voert dit uit en is er ook voor verantwoordelijk (Steenbeek et al, 2004). In het geval van een externe leverancier noemen we het outsourcing, in het Nederlands uitbesteding.
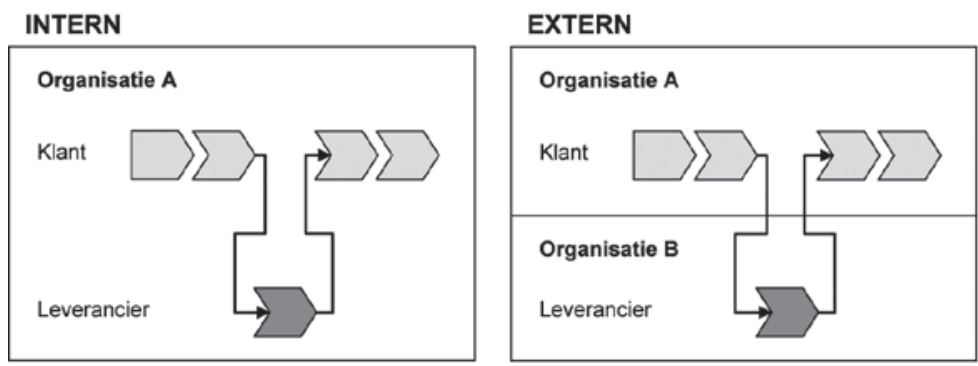

Figuur 4 Interne sourcing en Outsourcing

Wanneer activiteiten worden uitbesteed van de ene naar de andere organisatie, ontstaan samenwerkingsrelaties. Een organisatie heeft bijvoorbeeld een "vaste" leverancier, die door een langdurige relatie veel meer waarde aan de klant kan bieden dan een eenmalige leverancier. Daarnaast zijn bij een dergelijke langdurige relatie minder problemen met betrekking tot de betrouwbaarheid en aanspreekbaarheid van de leverancier. Als men de samenwerkingsvorm en de duur van de relatie in acht neemt bij het nemen van sourcingbeslissingen, spreken we van "strategische sourcing".

Een sourcingstrategie heeft vier dimensies:

- Waarom: doelen/motieven van sourcing;

- Wat: wat te sourcen;

- Hoe: de wijze waarop een organisatie kan sourcen;

- Waar: de sourcinglocatie.

Zoals bijelkebeslissing,sturendelT-doelen (afgeleidvandeorganisatiedoelen) het nemen van een sourcingbeslissing. Sourcing wordt hierdoor niet een eenmalige beslissing van in- of outsourcen van bijvoorbeeld de gehele 
IT-afdeling, maar een sourcingmix per proces of activiteit. Er moet bij elke sourcingbeslissing rekening worden gehouden met alle doelen, om op die manier het overkoepelende organisatiedoel te behalen.

De Looff (1996) identificeert zes basisargumenten waarom een organisatie kan besluiten over te gaan tot een andere manier van sourcing: kostenreductie, lead-time, kwaliteit, flexibiliteit, controleerbaarheid en continuïteit. Cavusgil, Yaprak en Yeoh (1993) identificeren kostenreductie, kwaliteitsverbetering, toegang tot wereldwijde (internationale) technologie en verbetering van leveringsbetrouwbaarheid als sourcingmotieven.Verhoef(2003) noemtspeed-to-market,kostenreductie, opbrengsten en kwaliteit.

Yang \& Huang (2000) delen sourcingmotieven in op vijf dimensies: management, strategie, technologie, economie/financiën en kwaliteit. Binnen elke dimensie is een aantal motieven voor sourcing aan te wijzen.

Tabel 1 Sourcingmotieven (Yang \& Huang, 2000)

\section{Management}

- Stimulate IS department to improve their performance and enhance morale

- Improve communication problems and selfishness between IS departments and operational department

- Solve the floating and scarcity of employee

- Increase the ability of management and control of IS department

- Keep the flexibility to adjust department, including consolidation or decentralization

\section{Strategy}

- Focus on core competence

- Make strategic alliance with vendor to make up the shortage of resources or technology

- Form a new company by concatenating core competencies of these strategic alliances to develop new product \& sell

- Share the risks

- Time to market

\section{Technology}

- Get new technology

- Learn new technology of software management and development from vendors

\section{Economics}

- Reduce the developing and maintaining cost of information systems

- Make the fixed costs to become to variable costs

- Increase the flexibility in finance

\section{Quality}

- Procure higher reliability and performance of IS

- Reach higher service level 
Welke IT-processen/activiteiten worden gesourced en welke terminologie wordt hiervoor gebruikt? Natuurlijk kan elk IT-proces gesourced worden (intern uitvoeren is immers ook sourcen), maar dat is een wel erg beperkte keuze. Het is dus nodig die IT-processen te identificeren die zowel in- als uitbesteed kunnen worden. De Looff (1996) heeft een analyse gemaakt van relevante modellen. Hieruit leidt hij zes factoren af, aan de hand waarvan een organisatie kan beslissen of outsourcing van een informatiesysteem mogelijk is. Deze factoren zijn ook breder toe te passen, namelijk op de IT-processen/activiteiten in een organisatie. De zes factoren zijn: strategicness (strategische waarde), market pressure, control, power, information asymmetry en economies of scale.

De zes factoren vormen samen een beslismodel waarmee geïdentificeerd kan worden of een proces uitbesteed kán (maar niet noodzakelijk dient te) worden. In andere sourcingliteratuur wordt vaak slechts één of twee factoren benoemd die de sourcingbeslissing beïnvloeden. De bekendste daarvan is de strategische waarde (van een proces). Deze wordt hieronder verder uitgewerkt.

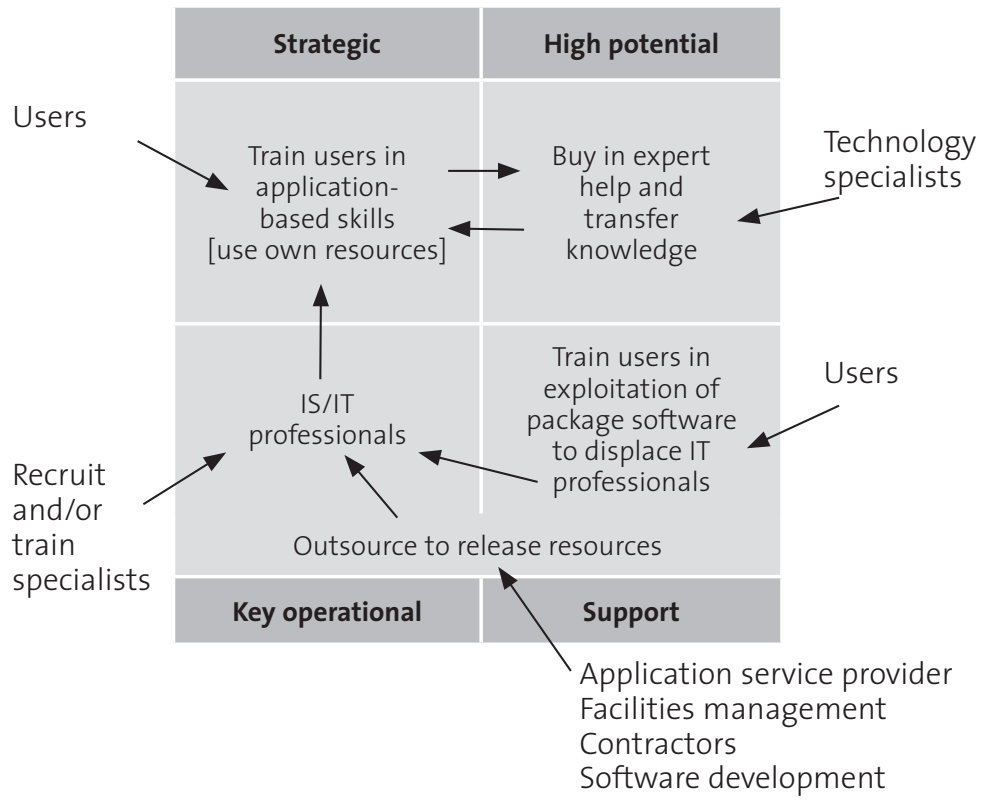

Figuur 5 Applicatieportfolio in relatie tot outsourcing (Ward \& Peppard, 2002) 
Een dimensie van sourcing is de manier van "interactie tussen twee of meer aparte maar onderling afhankelijke spelers". Deze interactie kan zowel kort (ad-hoc) als lang duren. Korte-termijn contractering (traditionele sourcing) gebeurt vooral met één leverancier die door eerder uitgevoerde klussen het vertrouwen van de klant heeft gewonnen (Currie \& Willcocks, 1997). Zoals eerder uitgelegd, zijn lange-termijn relaties met een leverancier (strategische sourcing) op dit moment populairder. Drie lange-termijn relaties worden door De Man et al. (2001) geïdentificeerd: strategische leveranciers, allianties en netwerken. Deze opdeling is eigenlijk een combinatie van twee factoren, namelijk het aantal spelers en het doel van sourcing. In een partnerschap bestaan er twee spelers en draait het om het leveren van een specifiek product of bepaalde dienst. Een alliantie heeft ook twee spelers, maar hier wordt iets nieuws ontwikkeld. Tot slot bestaat een netwerk uit drie of meer spelers, en is het doel het combineren van kennis om complexe oplossingen aan te kunnen bieden.

Tabel 2 Vormen van sourcing

$\begin{array}{lll}\text { Sourcingvorm } & \text { Aantal leveranciers } & \text { Insourcing / outsourcing } \\ \text { Internal delivery } & 1 & \text { Geheel intern } \\ \text { Insourcing } & 1 & \text { Intern } \\ \text { Single sourcing } & 1 & \text { Extern } \\ \text { Sole sourcing } & 1 & \text { Extern } \\ \text { Dual sourcing } & 2 & \text { Extern, evt. ook intern } \\ \text { Joint venture } & 2 & \text { Intern / extern } \\ \text { Prime contractor } & 3 \text { of meer (1 contact) } & \text { Extern } \\ \text { Best-of-breed consortium } & 3 \text { of meer (1 contact) } & \text { Extern } \\ \text { Multiple sourcing } & 3 \text { of meer } & \text { Extern, evt. ook intern } \\ \text { Parallel sourcing } & 2 \text { of meer } & \text { Extern, evt. ook intern }\end{array}$

Niet alle sourcingrelaties kunnen echter in één van de drie categorieën geplaatst worden. Om dit te bereiken, is een andere manier van indeling is nodig. Het gehele spectrum van relaties kan weergegeven worden door het aantal spelers als opdelingsfactor te gebruiken, gecombineerd 
met in hoeverre sourcing 'intern' of 'extern' plaatsvindt. In Tabel 2 zijn deze twee dimensies in tabelvorm neergezet.

Zoals gezegd kan sourcing op verschillende locaties plaatsvinden: global sourcing of, in het Nederlands, wereldwijd verspreid werk. Mol (2001) definieert global sourcing als "The decision-making process through which firms find and manage inputs for final production in an integrated, international context in order to contribute to the creation of sustainable competitive advantage by the firm".

Er wordt een aantal mogelijke opties onderscheiden, zoals sourcing bij de klant zelf (in hetzelfde gebouw), in het land waar de klant is gevestigd, in buurlanden, of op andere continenten. De bekendste vorm van sourcing op een andere locatie dan die van de klant is ongetwijfeld offshore outsourcing. Bij offshoring wordt de service geleverd in een andere regio van de wereld (een ander continent dan de klant). Deze vorm van outsourcing krijgt de meeste aandacht in de media en wordt vaak gezien als dé oplossing bij sourcingbeslissingen met betrekking tot kosten reductie. Bij het nemen van een sourcingbeslissing moeten echter factoren als communicatieproblemen, kwaliteit van werknemers en beveliging van bedrijfsinformatie in ogenschouw worden genomen. Hier kom ik later nog op terug. In offshore outsourcing spelen deze factoren een vaak onderschatte rol. In mijn organisatie hanteren we dan ook een speciale term om de juiste wijze van sourcing met betrekking tot locatie aan te duiden: rightshore sourcing, ofwel Rightshoring. Door middel van service centers met dezelfde look-and-feel kunnen activiteiten verdeeld worden over verscheidene centers (de portfolio), zonder dat de klant een verandering in de dienstverlening waarneemt. Zo zijn we in staat om een min of meer naadloos proces te doorlopen van bijvoorbeeld Heerlen naar Utrecht naar Hyderabad.

Naast traditionele offshore landen als India zijn ook andere Aziatische landen in opkomst. Het is de verwachting dat, net als in bijvoorbeeld de textielindustrie, ook in de IT-industrie werk zich gaat verplaatsen, en vooral daar gaat plaatsvinden waar het op dat moment het best (en vaak is dat: tegen de laagste kosten) kan worden uitgevoerd. In Figuur 6 zijn diverse vestigingslanden aangegeven. 


\begin{tabular}{|c|c|c|c|}
\hline $\begin{array}{l}\text { Leader } \\
\text { India }\end{array}$ & & $\begin{array}{l}\text { Up and Comers } \\
\text { Belarus } \\
\text { Brazil } \\
\text { Caribbean } \\
\text { Egypt } \\
\text { Estonia } \\
\text { Latvia }\end{array}$ & $\begin{array}{l}\text { Lithuania } \\
\text { New Zealand } \\
\text { Singapore } \\
\text { Ukraine } \\
\text { Venezuela }\end{array}$ \\
\hline Challengers & & Beginners & \\
\hline $\begin{array}{l}\text { Canada } \\
\text { China } \\
\text { Czech Republic } \\
\text { Hungary } \\
\text { Ireland } \\
\text { Israel }\end{array}$ & $\begin{array}{l}\text { Mexico } \\
\text { Northern Ireland } \\
\text { Philippines } \\
\text { Poland } \\
\text { Russia } \\
\text { South Africa }\end{array}$ & $\begin{array}{l}\text { Bangladesh } \\
\text { Cuba } \\
\text { Ghana } \\
\text { Korea } \\
\text { Malaysia } \\
\text { Mauritius }\end{array}$ & $\begin{array}{l}\text { Nepal } \\
\text { Senegal } \\
\text { Sri Lanka } \\
\text { Taiwan } \\
\text { Thailand } \\
\text { Vietnam }\end{array}$ \\
\hline
\end{tabular}

Figuur 6 Vestigingslanden voor IT-activiteiten

De vraag, welke mix van 'waarom', 'wat', 'waar' en vooral 'hoe' optimaal is, is niet eenduidig te beantwoorden. Immers, elke situatie is weer anders. Met behulp van de voorgaande paragrafen en een recent wetenschappelijk onderzoek naar sourcingfactoren (zie bijv. Steenbeek et al, 2005) kunnen we echter wel relaties tussen dimensies aangeven. Het gaat hierbij om relaties tussen:

- Activiteiten (dus 'wat') en sourcingvorm ('hoe');

- Doelstellingen (dus 'waarom') en locatie ('waar') / sourcingvorm.

We geven hieronder kort aan, wat die relaties zijn.

Welke sourcingvorm voor een bepaalde activiteit te kiezen is afhankelijk van een aantal criteria:

1. Afhankelijkheid van de externe partij. In welke mate is afhankelijkheid van een externe partij gewenst? In hoeverre is het gewenst om bij een externe partij geplaatste apparatuur wel/niet in eigendom te hebben? Dit hangt samen met het aspect flexibiliteit - hoe flexibel is een organisatie ten aanzien van zijn kritische processen in kritieke situaties?

2. Relatie met een externe partij. In welke mate is het gewenst of noodzakelijk om een relatie met een externe partij op te bouwen en te bestendigen? In sommige gevallen kan een bestendige, langetermijn relatie met een leverancier, die wellicht duurder is dan mede-bieders, toch gunstiger uitpakken.

3. Afhankelijkheid van andere activiteiten. In hoeverre is de activiteit afhankelijk of 'verweven' met andere, niet of elders uit te besteden 
activiteiten? Kan de activiteit worden geïsoleerd? Gerelateerd hieraan: in hoeverre staat de uit te besteden activiteit op zich zelf in de bedrijfs-en IT-architectuur van de organisatie, of maakt zij deel uit van een cluster activiteiten die niet los van elkaar te zien zijn.

4. Positionering van de uit te besteden activiteit. In hoeverre is een activiteit bijvoorbeeld uit te besteden bij een externe partij gelet op het strategische karakter van die activiteit.

5. Flexibiliteit. Enerzijds is een externe partij in staat om snel in te spelen op de vraag om extra resources dan wel resources met specifieke kennis, anderzijds kan de snelheid van handelen bij zelf doen hoger liggen in 'ad hoc' situaties.

6. Kennisopbouw. In hoeverre is het (on-)gewenst dat een organisatie wel/niet kennis heeft of opbouwt op het gebied van bepaalde (nieuwe) technologieën?

7. Scope: alle resources behorend bij een activiteit (dus apparatuur én personeel), alleen personeel of alleen apparatuur.

8. Bescherming van confidentiële / concurrentiegevoelige informatie. In hoeverre is deze bescherming te waarborgen in geval van uitbesteding?

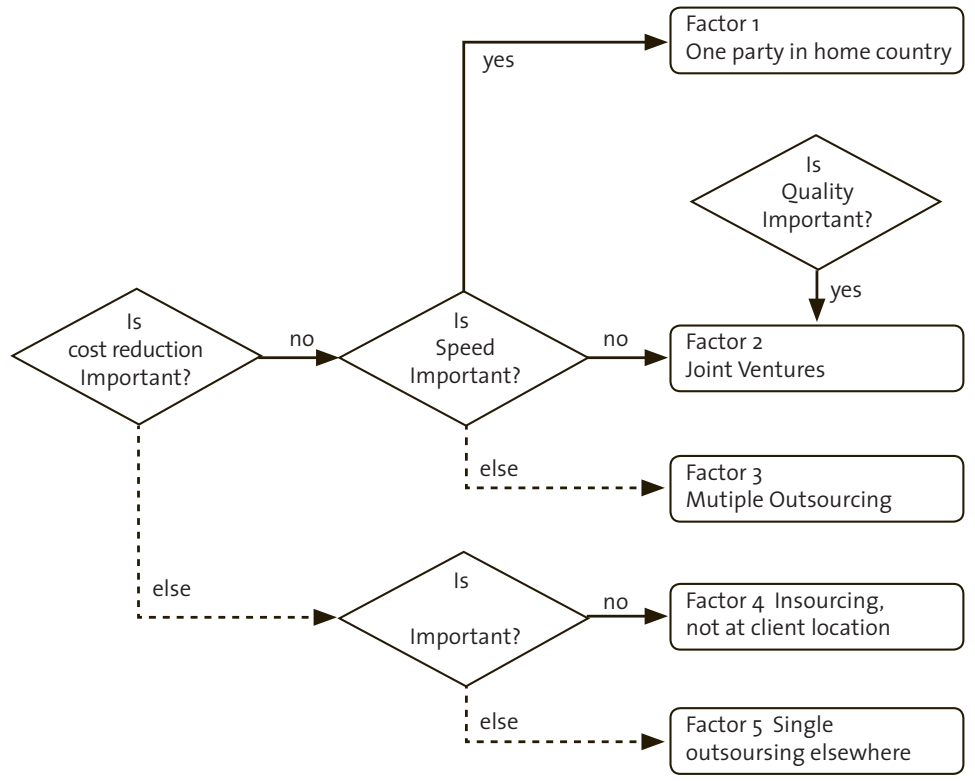

Figuur 7 Beslissingsboom sourcingvorm/-locatie 
Als het antwoord op de 'waarom'-vraag bekend is, kan met een behoorlijke mate van zekerheid de bijbehorende combinatie van sourcinglocatie en -vorm worden gevonden met behulp van onderstaand schema (zie voor een uitgebreide toelichting/onderbouwing hiervan Steenbeek et al, 2005).

Het blijkt, dat de volgende relaties, in meer of minder sterke vorm, bestaan:

- Als kwaliteit een belangrijke doelstelling is, dan biedt de Joint Venture vorm een hoge succeskans. Dit geldt ook, indien kostenreductie en snelheidsverbetering relatief minder belangrijk zijn.

- Als kostenreductie in ieder geval niet onbelangrijk is (dit kan ook betekenen, dat het niet bekend is of kostenreductie wel of niet belangrijk is!) en flexibiliteit is onbelangrijk, dan is er een hoge kans op succes indien gekozen wordt voor insourcing op een andere plaats dan die van de klant. Indien flexibiliteit niet onbelangrijk is, is in dat geval outsourcing naar één partij in het buitenland aan te bevelen.

- Als kostenreductie onbelangrijk is en snelheidsverbetering is dat wel, is kans op het succes het hoogst als gekozen wordt voor outsourcing in eigen land.

- Als kostenreductie onbelangrijk is en snelheidsverbetering is onbelangrijk noch belangrijk, is de kans op succes het grootst als gekozen wordt voor uitbesteding bij meer dan één partij.

Zoals gezegd is kennis op vele plekken aanwezig in het IT-proces. Het is productiemiddel, maar ook resultaat van dat proces. Kennis is iets was tussen de oren van mensen zit. Het is heel lastig om kennis expliciet te maken, ook kennis is abstract. Hierbij komt nog eens het onderliggende probleem dat we ons van bepaalde soorten kennis niet eens bewust zijn (Polanyi, 1958).

Op het moment dat we werk gaan verdelen, moeten we kennis gaan overdragen. Vanwege het abstracte karakter van kennis, wordt overdracht vrij lastig. Toch is die kennisoverdracht, en ook het behoud en vermeerderen van kennis, cruciaal voor het welslagen van wereldwijd verspreid werk. Het verkrijgen, beschrijven overdragen, behouden en vermeerderen van kennis noem ik kennismanagement (in een latere fase van deze rede kom ik nog op deze "definitie" terug). Mijn stelling is: kennismanagement is één van de pijlers voor het wereldwijd verspreiden 
van werk, en dit geldt in het bijzonder voor IT-werk. Waarom is dat zo? Ik noem een aantal factoren (Harmsen \& van den Brand, 2006):

Cultuur. Als je werk op verschillende plaatsen op de wereld uitvoert, bestaan tussen de betrokkenen vaak grote cultuurverschillen. Deze cultuurverschillen leiden soms tot miscommunicatie. De beleving van zaken is dan wezenlijk anders. Een bekend voorbeeld is verwachtingsmanagement: Een Nederlander is direct en bedoelt, meestal, met 'Nee' ook echt 'Nee'. Voor een Aziaat ligt dat heel anders, omdat hij het onbeleefd zal vinden om 'Nee' te zeggen. Ik heb het te vaak meegemaakt dat ik als "botte Hollander" een vraag stelde aan een Indiër, die altijd met "yes" werd beantwoord. In de helft van de gevallen werd eigenlijk een "no" bedoeld. Beloftes zullen daardoor in de praktijk vaak niet tot het gewenste resultaat leiden. Overigens slijt dit culturele onderscheid snel. Naarmate we meer met elkaar samenwerken, begrijpen Westerlingen en Aziaten elkaar beter. Begrip is essentieel voor kennismanagement, dus kennismanagement vergt ook en vooral veel onderlinge communicatie en samenwerking. Het simpelweg "over de muur gooien" werkt niet.

Geografie. Is het bij bijvoorbeeld een systeemontwikkelproject dat op één plek plaatsvindt nog mogelijk om als gebruiker heel even bij de programmeurs langs te lopen, bij offshore is dit niet mogelijk. Het overbruggen van een intercontinentale afstand vraagt meestal enkele uren vliegen. Elkaar regelmatig spreken, workshops, team building en dergelijke brengt dan al gauw onvoorziene hoge kosten met zich mee. De fysieke afstand bemoeilijkt dus de kennisoverdracht.

Tijdsverschil. Tussen de klant en de leverancier bestaat een tijdsverschil. Bij het uitbesteden van werk van Nederland naar India bedraagt dit tijdsverschil minimaal 3,5 uur, bij het uitbesteden naar China zelfs 7 uur. Dit betekent dat als de dag begint in Nederland, de werkdag eindigt in China. Hierdoor wordt overleg en afstemming beperkt. Bij landen dichter in de buurt (bijvoorbeeld Noord Afrika of Oost Europa) geldt deze beperking uiteraard niet of in veel mindere mate.

Zeggenschap.Vaak besteedt een bedrijf, de klant, een deel van het IT-werk uit bij een leverancier. Over die leverancier heeft de klant dan geen zeggenschap. Dit leidt ertoe, dat de klant geen grip heeft op het proces van de leverancier. Daardoor zal het onduidelijk zijn hoe het proces van 
de klant aansluit op het proces van de leverancier. Voorbeeld hiervan is de wijze waarop bijvoorbeeld de eisen en wensen die een klant heeft moeten worden aangeleverd. Onduidelijkheid hierin zal ongetwijfeld leiden tot onbegrip. En dat zal vaak niet een goede "fit" opleveren tussen wat nodig is en wat uiteindelijk geleverd wordt.

Taal. Hoewel veel IT-leveranciers hun communicatie in het Engels voeren (zowel mondeling als schriftelijk), zijn klant en leverancier bijna gedwongen in een vreemdetaal met elkaar te communiceren. Juist als het gaat om kennisoverdracht gaat het dan mis. Taal is ontzettend belangrijk voor kennisoverdracht. Rapportages in "Denglish" (Dutch English) en "Penglish" (Polish English) zullen leiden tot miscommunicatie.

Stabiliteit. Een aantal landen waar IT-werk plaatsvindt, zijn politiek instabiel. Regeringen kunnen vallen, burgeroorlogen ontstaan. Een atoomoorlog tussen Pakistan en India is helaas een niet ondenkbeeldig scenario. In dat geval is niet zomaar alle Indiase IT-capaciteit in een andere regio voorhanden. Andere risico's die onder deze noemer vallen zijn het optreden van corruptie, criminaliteit en arbeidsconflicten, waardoor een stabiele relatie gevaar loopt. Een onrustige arbeidsmarkt, waardoor werknemers zich niet gebonden voelen aan één bedrijf en op elk concurrerend salarisaanbod van een concurrent ingaan, vergroot natuurlijk ook niet die stabiliteit. Hierdoor kunnen gemaakte afspraken en overeenkomsten plotseling waardeloos worden. Een klant wil graag deze risico's beperken, maar tegelijkertijd ook de voordelen plukken van goedkopere tarieven in een aantal politiek instabiele landen en regio's.

Beveiliging. Bij het verdelen van IT-werk wordt een deel van de bedrijfsvoering van de klant op tafel gelegd. Indien de bedrijfsvoering van strategische aard is, dan is beveiliging een issue. Dit betreft niet alleen beveiliging van data, maar ook intellectueel eigendom.

Wetgeving. De strenge privacywetgeving in Europa is een barrière voor het verdelen van werk over de wereld. Indien data de Europese grens overgaan, gelden zeer strakke bepalingen. Aan die bepalingen moet via een juridisch dichtgetimmerd contract worden voldaan. Het uitvoeren en managen van zo'n contract is vervolgens een hachelijke zaak, omdat de uitvoerders vaak niet het begrip kunnen opbrengen voor belemmeringen die het contract voor hen met zich meebrengt. 
Contract en werkelijkheid gaan dan uit elkaar lopen, met alle risico's op schending van privacywetgeving en inbreek op intellectueel eigendom van dien. Procederen in vreemde landen kost bovendien een hoop geld en levert vaak weinig op, nog afgezien van de reputatie- en imagoschade die in eigen land wordt geleden. Dit geldt overigens niet alleen voor privacywetgeving, maar ook voor wet- en regelgeving als SarbanesOxley, Basel II en IFRS.

Vanwege voorgaande factoren moet expliciet aandacht worden besteed aan het vinden, vergaren, verspreiden, opslaan en verwijderen van kennis. Met andere woorden: kennis moet, als het gebruikt wordt in werk dat wereldwijd wordt verspreid, worden gemanaged. 


\section{Kennismanagement}

Alle bovengenoemde factoren hebben iets gemeenschappelijks: het gaat altijd over afspraken, over taal, over rapporten die opgeleverd moeten worden, over contracten, wetgeving, communicatie. Het gaat altijd over kennis. Op deze plek wil ik graag een klassieker in de Informatica behandelen: het verschil tussen gegevens, informatie en kennis (o.a. Ackoff, 1989). De meeste informatici zullen "gegevens" definiëren als symbolen, als vastgelegde feiten, zonder betekenis anders dan dat ze bestaan. Het getal 100 op de snelheidsmeter van mijn auto is een gegeven - iemand die niets weet van snelheid zal het als een abstract getal opvatten. Informatie is geïnterpreteerde gegevens, gegevens met een betekenis. 100 is informatie, omdat ik weet dat het $100 \mathrm{~km}$ per uur betekent. Kennis is de toepassing van informatie: Als ik $100 \mathrm{~km}$ per uur op een woonerf rijd, weet ik dat er vroeg of laat slachtoffers gaan vallen.

Kennis is enerzijds het cognitieve proces van het toepassen van gegevens en informatie (iets wat een mens met zijn zintuigen en zijn hersenen doet), maar anderzijds ook de verzameling verwerkte gegevens en informatie (bewust of onbewust opgeslagen in de hersenen). De afspraken die gemaakt worden tussen de Nederlander en de Roemeen over een nieuw orderverwerkingssysteem behelzen kennis bij zowel de Nederlander als de Roemeen. Beide nemen de afspraken zintuiglijk waar (al dan niet in het Engels en al dan niet met hun ogen of hun oren), beide interpreteren ze, beide geven er een bepaalde betekenis aan. Kennis is dus iets inherent persoonlijks, iets waarop ik iets verderop in deze rede nog zal terugkomen.

De literatuur over de aard van kennis onderscheidt enerzijds het verschil tussen "impliciete" (tacit) kennis en "expliciete" (codified) kennis (Nelson \& Winter, 1982; Polyani, 1966) en anderzijds of kennis gaat over de toestand van de wereld - dus gaat het over het "wat" - of dat een bepaalde competentie - het "hoe" - betreft (Garud, 1997; Lundvall \& Johnson, 1994). Expliciete kennis kun je vastleggen, bijvoorbeeld in een taal, terwijl impliciete kennis vaak heel context-specifiek is.

Impliciete en expliciete kennis zijn uiteinden van een spectrum, geen elkaar uitsluitende categorieën. Een voorbeeld van vrij expliciete kennis is een formele procedure om een vliegtuig te starten. Een voorbeeld van 
vrij impliciete kennis is een "ongeschreven regel" die een groep kent. Impliciete kennis kan expliciete kennis worden - een bekend voorbeeld daarvan is de medische wetenschap, waarin immers vroeger vrijwel uitsluitend impliciete kennis bestond over de genezing van kwalen, kennis die nu is vastgelegd in procedures en handboeken (Vosburgh \& Newbower, 2000).

Er is ook een onderscheid tussen sociale kennis en technische kennis. Technische kennis is in het algemeen wat explicieter dan sociale kennis, omdat heel veel aspecten van gedrag, cultuur en coördinatie in organisaties niet te vangen zijn in woorden of symbolen. Sociale kennis is daarom veel meer een kwestie van de intuïtieve beoordeling wie je moet kennen om wat te weten (het bekende "ons kent ons") en wie je kunt vertrouwen.

De diverse kennistypen worden opverschillende manieren overgedragen. Juist als het gaat om kennismanagement op een wereldwijde schaal, is het belangrijk om te weten welke kennis je op welke manier moet overdragen. Expliciete kennis kan worden overgedragen met behulp van documenten en handboeken. Als het echter gaat om kennis van het "hoe", en daar gaat het vooral om als we het over wereldwijd verspreid werk hebben, zal er ook training en instructie aan te pas moeten komen, maar overdracht is dan nog steeds relatief eenvoudig (Teece, 1977). Als het echter gaat om impliciete kennis, dan is nabijheid en interactie tussen personen noodzakelijk (Hansen, 1999; Sole \& Edmondson, 2002). Je gebruikt dan mechanismen als coaching, stages en herhaaldelijk oefenen om kennis over te dragen. Medische routines die bepaalde subtiele oordeelsvorming verlangen (impliciete knowhow) kunnen daarom van regio tot regio verschillen (Wennberg, 1977). Als kennis moeilijk over te dragen is (dat wil zeggen als het fysieke nabijheid vergt om kennis te zien, te begrijpen en te oefenen voordat het in de praktijk kan worden gebracht), dan is het waarschijnlijk dat er lokale verschillen gaan ontstaan in de wijze waarop de kennis wordt toegebracht (Edmondson, 2003).

Kennis is a priori het bezit van een individuele persoon en afhankelijk van de mate waarin het expliciet te maken is, het om technische of sociale kennis gaat en of het om het "wat" of het "hoe" gaat, kan kennis ook het bezit worden van een groep. 
Kennismanagement is een poging om kennis van het persoonlijke naar het collectieve perspectief te verplaatsen. Natuurlijk is de term zelf in bepaalde opzichten onzin, bijna een contradictio in terminis. Hoe kun je immers iets managen wat, soms zelf on- of onderbewust, in de hersenen van ieder individu plaatsvindt? Het gaat uit, als je het heel negatief stelt, van een wat mechanistische, technocratische blik op de wereld, die met name bij consultancy firms en informatici populair is geworden. Toch heeft de term al een vrij lange historie, die ups and downs heeft gekend.

Goed kennismanagement maakt gebruik van een gemeenschappelijke taal. Eigenlijk zou je beter kunnen spreken over een gemeenschappelijk terminologiekader, ontologie genoemd. Een ontologie zou je kunnen vergelijken met een woordenboek, waarin termen en de relaties tussen die termen worden uitgelegd. Dat gemeenschappelijke kader, die ontologie, is van cruciaal belang voor kennismanagement. Kennis bestaat uit immers uit toepassen van informatie en gegevens, en die gegevens moeten wel eenduidig begrepen worden om ook daadwerkelijk betekenis te hebben. Beschouw bijvoorbeeld maar eens het woord "oorvijg". lemand die dit woord niet kent (bijvoorbeeld een buitenlander die het voor het eerst in een Nederlandse zin hoort), zou het kunnen interpreteren als een lichaamsdeel, iets wat met je oor verbonden is. Hij zou het ook kunnen interpreteren als een bepaald soort vijg, iets wat je opeet. Pas met een woordenboek bij de hand, en wellicht de context waarin het woord wordt gebruikt, zal hem duidelijk worden dat het woord oorvijg helemaal niets met lichaamsdelen of vruchten te maken heeft!

Een term, een gegeven, heeft altijd een aantal aspecten (cf. Stamper 1988):

- Het sociale aspect, met noties als cultuur, verwachtingen en overtuigingen. Een Nederlander zal al snel het woord oorvijg associëren met iets negatiefs, terwijl een buitenlander dus de positieve notie van een lekkere vrucht zou kunnen hebben.

- Het pragmatische aspect, dat de bedoeling van een term weergeeft. Een oorvijg is bedoeld om een ander te straffen.

- Het semantische aspect, dat de betekenis en interpretatie van een term aanduidt. Een oorvijg is niets meer en niets minder dan een klap, meestal tegen het oor. 
- Het syntactische aspect, dat de notatie en uitspraak weergeeft. In het geval van de oorvijg gaat het om de letters o, o, r, v, ij en g. Je spreekt het op zijn Nederlands uit.

- Het empirische aspect, waarmee het patroon en de structuur van de term wordt aangeduid. De letter o is bijvoorbeeld een cirkel en de lange ij bestaat uit twee verticale streepjes, allebei met een puntje erop, waarbij het tweede streepje aan de onderkant een haakje naar links heeft.

- Het fysieke aspect van een term. Ik spreek het woord oorvijg uit, maar in het boekje dat bij deze rede hoort, staat het op papier en in mijn laptop staat het, gecodeerd, als een stel nullen en enen.

Kennismanagement, dat natuurlijk vele malen complex is dan alleen maar het overbrengen van het woord 'oorvijg', heeft dus baat heeft bij een goed terminologiekader. De vraag die zich dan natuurlijk gelijk opdringt, is: wat is een goed terminologiekader? En: is het überhaupt wel mogelijk om een terminologiekader te hanteren? Immers, wij mensen percipiëren de realiteit allemaal op een andere manier. Zeker als je met verschillende culturen te maken hebt, en dat hebben we, leidt dat tot interessante onderzoeksvragen. Vragen die ook nog eens sterk verband houden met de filosofische positie die je als mens inneemt. Grofweg zijn de volgende posities mogelijk (Falkenberg et al, 1998):

- De objectivistische, die gelooft dat er één realiteit is, onafhan kelijk van welke observatie en interpretatie - de realiteit en de gepercipieerde realiteit zijn hetzelfde

- De constructivistische, die ook in één realiteit gelooft, maar tegelijkertijd ook erkent dat elk mens de werkelijkheid anders begrijpt en percipieert. Realiteit en gepercipieerde realiteit zijn dus niet hetzelfde.

- De mentalistische, die ontkent dat er één realiteit is. De realiteit wordt immers begrepen en gepercipieerd door de menselijke zintuigen en is derhalve volkomen afhankelijk van persoonlijke observatie en interpretatie. Het praten over één werkelijkheid is dus, volgens de aanhangers van deze positie, onzin.

Ikzelf hanteer de constructivistische visie, waarmee ik dus erken dat er een verschil bestaat tussen werkelijkheid en gepercipieerde werkelijkheid. In aanmerking nemende dat een gemeenschappelijk terminologiekader van wezenlijk belang is voor goed kennismanagement, betekent dat dus dat ik in mijn leerstoel effectieve ontologieën onderzoek: 
terminologiekaders, gemeenschappelijke kaders zo u wilt, waarmee kennis op een wereldwijde schaal kan worden verkregen, beschreven, gedeeld, behouden en vermeerderd.

Dat klinkt allemaal erg ingewikkeld en complex. Complexiteit is de grootste valkuil van en voor kennismanagement. Ik erken onmiddellijk dat consultancy firms en wetenschappers de neiging hebben om dingen ingewikkelder te maken dan ze zijn. Deconsultancy firms verdienen er veel geld mee, en wetenschappers hopen er mooi, fundamenteel onderzoek mee te doen, dat ook nog eens een boel publicaties oplevert. Ondanks het feit dat ik die twee werelden min of meer in één persoon verenig, pleit ik voor een hele simpele benadering van kennismanagement. In mijn praktijk waren de simpelste vormen altijd de meest succesvolle. Het mooiste voorbeeld hiervan betrof een project dat ik jaren geleden voor een grote bank deed (Harmsen \& Kleijnen, 2003). Het kennismanagement in dat project, en later werd dat uitgebreid naar andere projecten, stoelde op drie pijlers:

1. Een écht team enthousiaste mensen dat dicht bij elkaar zat, voor elkaar door het vuur ging en elkaar dagelijks op de hoogte hield. Het ging om het team, en om de locatie.

2. Eén proces, in dit geval de ontwikkelmethode DSDM. Elk teamlid kende en begreep deze methode en het terminologiekader dat ermee samenhing. De methode was in één dag te leren en was gebaseerd op een aantal "gezond verstand" principes.

3. Een heel simpel geautomatiseerd systeem, gebaseerd op het "Startpagina"-concept. In dit verband wil ik graag mijn collega Leo Diepstraten noemen, die de geestelijk vader van dit systeem was. Elke medewerker had een startpagina waarop op een zeer overzichtelijke wijze verwijzingen naar relevante informatie stonden vermeld. Tegenwoordig zouden we dit een 'portal' noemen.

Ik geef onmiddellijk toe dat kennismanagement op een wereldwijde schaal met name voor wat betreft het team- en locatieaspect, en ook het procesaspect, lastiger te regelen is. Maar eenvoud en simplisme blijven ook dan kritieke succesfactoren voor goed kennismanagement. Uiteraard kom ik hierop nog terug.

Naast de noodzaak van een gemeenschappelijke taal en het zo simpel mogelijk benaderen van het probleem, is er nog een laatste aspect van goed kennismanagement dat ik wil noemen: toesnijden op de situatie. 
Ik illustreer dat met een belangrijke bron van kennis: de methode. In de begintijd van de Informatica waren er nauwelijks gestructureerde methodes om problemen gestructureerd en gecoördineerd mee aan te pakken. Ook kennismanagement leed daar onder. Men deed maar wat. In de jaren '70 en '80, en deels ook nog in de jaren '9o, leidde tot vele methoden, beschreven in dikke boeken (Harmsen, 1997). Die methoden waren geschreven door knappe koppen. Heel veel kennis over het domein van die methoden, bijvoorbeeld systeemontwikkeling, of projectmanagement, bundelden ze in die dikke boeken. Er waren methoden die gewoon in de boekwinkel te koop waren, maar consultancy bureau's vroegen er heel veel geld voor, met als motivatie, inderdaad, dat de in hun methoden opgeslagen kennis heel veel waard is. Zo werden soms bedragen van tonnen gevraagd voor die methoden, een hele expliciete manier om aan te geven dat kennis kapitaal vertegenwoordigt.

Geweldige kennisbronnen waren het, maar voldeden die dikke boeken ook? Om die vraag te beantwoorden, neem ik u even mee naar de praktijk van alledag. Een projectleider, laten we hem Pascal noemen, heeft de opdracht gekregen om projectmatig een informatiesysteem te realiseren. Pascal is een ervaren projectleider. Het eerste wat Pascal doet, is het maken van een plan. Vervolgens gaat hij dat plan uitvoeren. Denkt $u$ nou echt dat Pascal een dik boek van de plank pakt, bij pagina 1 begint te lezen en elke aanwijzing in de methode opvolgt om zijn plan te maken en dat vervolgens uit te voeren? Zoals elke rechtgeaarde vakman vertrouwt hij op zijn eigen kennis en ervaring, en haalt dat niet uit een boek. En ja, tegenwoordig staan die methoden niet meer in een boek (maar op Internet), maar het principe dat een handleiding, een kookboek zo $u$ wilt, de kennis verschaft die nodig is om een activiteit uit te voeren gaat niet op voor professionals met soms tientallen jaren ervaring. Zo'n boek zou op tientallen situaties toepasbaar moeten zijn, en dat is per definitie onmogelijk.

Wat heeft zo'n professional dan wel nodig? Hij gebruikt zo'n methode op drie manieren:

- Als naslagwerk, om even op te zoeken "hoe iets ook al weer zit".

- Als hulpmiddel om taken die nieuw voor hem zijn uit te voeren.

- Als hulpmiddel om een bepaalde voorgeschreven standaardisatie van producten te bereiken. 
Het woord "hulpmiddel " gebruik ik niet voor niets twee keer. Een methode, of welke vorm van kennismanagement dan ook, moet vooral een hulpmiddel zijn. Om dit te bereiken, moet de methode situationeel zijn (Harmsen et al, 1994). De kennis die in zo'n methode is opgeslagen moet op de situatie waarin hij wordt gebruikt zijn toegespitst. Dus geen kookboek met recepten die stap voor stap moeten worden opgevolgd, maar de "Larousse de la Gastronomie", eventueel gecombineerd met een kookcursus en wat andere 'methodefragmenten' (Brinkkemper, 1996).

Voor werk dat over de wereld is verdeeld geldt het situationele aspect nog veel meer. Elke situatie vereist een andere aanpak, en die situaties worden nou eenmaal talrijker als je de geografische dimensie toevoegt. Ik stipte al eerder aan dat termen cultureel en nationaal bepaald zijn dat zijn aanpakken ook. Werk dat over de wereld wordt verdeeld vereist kennismanagement dat heel specifiek op de situatie is toegespitst, en die situatie verschilt per locatie.

Goed kennismanagement heeft naar mijn mening dus minimaal drie kenmerken:

- Het maakt gebruik van een gemeenschappelijke taal, een gemeenschappelijk begrippenkader;

- Het is simpel;

- Het is situationeel - toegespitst op het werk dat je doet en aanwezig op de plek waar, en het tijdstip wanneer, je het nodig hebt.

De kunst is, om deze kenmerken te verenigen, want ze staan soms loodrecht op elkaar. De gemeenschappelijke taal lijkt in tegenspraak met het situationele aspect. En de schijnbare complexiteit die je introduceert door op verschillende locaties op de situatie toegesneden vormen van kennismanagement, of aanpakken, te gebruiken, lijkt niet bepaald simpel te zijn.

In mijn onderzoek probeer ik de drie kenmerken toch met elkaar te verenigen en toe te passen op wereldwijd verspreid werk. Mijn stelling is dat dit mogelijk is, mits er aan een aantal randvoor $\neg$ waarden is voldaan. Ik illustreer dat met een kort voorbeeld uit de praktijk.

Neem de productie van een nieuw televisietoestel van Sony. Een nieuw toestel wordt uitgedacht in de research \& development facilities in Tokyo. Het wordt ontworpen in Tokyo en Osaka, en een stuk van de Icd- 
component ook nog in Seoul. Het wordt vervolgens gefabriceerd en getest in Kuala Lum॰pur, Seoul en Guangzhou en geassembleerd in Guangzhou. Van daaruit wordt het naar de diver $\neg$ se landenimporteurs verspreid. Het is nog een relatief simpele case, omdat het hele proces zich in Azië afspeelt en omdat het om de fabricage van een concreet product gaat, en dus niet om puur ken nniswerk - maar juist door de eenvoud van de case kunnen we zien hoe in dit proces kennis wordt gemanaged.

Voor dit hele proces, van het uitdenken van het concept in Tokyo tot en met de assemblage in Guang $\neg$ zhou, is kennis nodig. De conceptuitdenkers maken gebruik van kennis die ze in hun opleiding hebben opgedaan, maar ook van handboeken en creatieve ingevingen. Ze maken schetsen en ont $\neg$ wer $\neg$ pen in een notatie die begrepen wordt door de technisch ontwerpers, los van de landstaal (Japans of Koreaans) die wordt gebruikt. De kennis die ze gebruiken is situationeel: toegespitst op hun R\&D-taak, en nergens anders op. Kennismanagement is vrij simpel: kennis wordt overgedragen in vergaderingen en opleidingssessies, dat is alles. Er is een hoge mate van standaardisatie, die elders in de electronica-industrie ook wordt gebruikt. Hetzelfde geldt voor de overdracht van tech $n$ nisch ontwerp naar fabricage, en van fabricage naar assemblage. Uiteindelijk resulteert het in een technisch hoogwaardig televisietoestel, met een productieproces dat wordt ondersteund door een kennismanagementproces dat gebruik maakt van één gemeenschappelijke taal en ook simpel en situationeel is. Wat is het geheim?

Het geheim lijkt communicatie te zijn. Effectieve en efficiënte communicatie is de sleutel tot het verenigen van de drie kenmerken gemeenschappelijke taal, eenvoud en situationele toepassing. Dit lijkt een open deur te zijn, omdat kennisoverdracht immers altijd uit communicatie bestaat. Toch zien we in onze dagelijkse praktijk dat het wel meevalt met die open deur:

- We "vergeten" te communiceren, bewust of onbewust.

- We gebruiken de verkeerde middelen om te communiceren. Ook communicatie is situationeel.

- We begrijpen elkaar niet. We maken het te moeilijk.

- We communiceren op verschillende "golflengtes". 
Kennismanagement van wereldwijd verspreid werk is gestoeld op de eerder genoemde drie kenmerken (taal, simpel, situationeel), met als grootste gemene deler communicatie. Voor bepaalde typen werkzaamheden is het prima om kennis via e-mail uit te wisselen, zelfs zonder dat de mensen die mailen elkaar kennen. Soms is een videoconferentie essentieel. Maar vaak heeft een videoconferentie weinig zin, als de deelnemers elkaar niet minstens één keer, zoals ik altijd zeg, "geroken en gevoeld" hebben. Dus een project dat zijn werkzaamheden in Amsterdam, Heerlen en Hyderabad uitvoert zal in het algemeen toch minimaal één keer "live" bij elkaar moeten zijn geweest voordat allerlei technologische communicatiemiddelen kunnen worden ingezet. 


\section{Kennismanagement van wereldwijd verspreid werk}

Kennismanagement gaat dus over communicatie. Maar wat onderscheidt wereld wijd verspreid werk nu van werk dat locaal wordt uitgevoerd? Wat maakt communicatie nou zo veel moeilijker als je werk over de aardbol distribueert, en hoe kun je het verbeteren?

Het is heel makkelijk gezegd: doe het werk daar waar je het het beste kunt doen. Nog los van de problemen en uitdagingen waarmee dit gepaard gaat, is het besluit om werk te verspreiden, om te sourcen, een lastige. Dat besluit is gestoeld op rationele, maar vooral ook op irrationele argumenten. De rationele zijn de makkelijkste. Veel consultancybedrijven bieden hulp en hulpmiddelen om dat besluit op rationele grondslagen te nemen. Zo heeft Capgemini hulpmiddelen als Application Portfolio Management (APM) en de Rightshore Assessment Study (RAS) (Jager et al, 2008). Dit soort studies bepaalt eerst het risico dat een organisatie wil lopen. Vervolgens wordt een onderzoek gedaan naar alle IT toepassingen in het onderzoeksdomein. In een grote organisatie kunnen dat er honderden, soms duizenden zijn. Voorbeelden van IT toepassingen variëren van de bekende Windows programma's tot personeelsadministraties en klantendatabanken. Vervolgens wordt van elke IT toepassing bepaald, wat er mee moet gebeuren: uitbesteden, verbeteren of misschien wel opdoeken. Een belangrijke factor daarbij is natuurlijk de verhouding tussen kosten en baten, de business case. Afhankelijk van het eerder bepaalde risico en business case wordt voor elke toepassing een plan gemaakt (bijvoorbeeld met als doelstelling uitbesteding naar India), dat dan wordt uitgevoerd. Het fysiek verplaatsen van zo'n toepassing is op zich niet het meest spannende: het gaat om het werk, en de mensen die dat werk doen, dat nodig is om een toepassing draaiende te houden en te verbeteren.

Een orderverwerkingssysteem, bijvoorbeeld, moet in het algemeen vrijwel altijd beschikbaar zijn voor zijn gebruikers - een bedrijf kan het zich niet veroorloven dat er geen orders meer verwerkt worden. Rond zo'n orderverwerkingssysteem bevindt zich een bepaalde brok ontwikkel- en onderhoudswerk: af en toe moeten er updates komen, moeten fouten hersteld worden, moet er iets aangepast worden. Als het orderverwerkingssysteem naar India wordt uitbesteed, verhuist het werk 
mee. De afstand tussen de gebruikers van het systeem, de personen met kennis over de materie 'orderverwerking' en de IT-ers die het systeem gaan onderhouden wordt dan een stuk groter. Kennismanagement wordt lastiger wanneer de afstanden groter worden - en dat worden ze, als je werk over de aarde verspreidt!

Verschillende soorten afstanden spelen een rol (Harmsen et al, 1995; Carmel \& Agarwal, 2001; Hofstede \& Hofstede, 2005; Gumm, 2006; Fabriek et al, 2007):

1. Fysieke afstand. Wanneer een deel van de werknemers in een ander deel van de wereld is, brengt dit fysieke beperkingen met zich mee. Face-to-face contact is beperkt mogelijk omdat heen en weer vliegen veel tijd en geld kost.

2. Afstand in tijd. Wanneer in verschillende tijdszones gewerkt wordt, wordt communicatie lastiger. Teamleden kunnen elkaar niet meer elk moment van de werkdag bellen. De tijd die men "samen" heeft is daarmee een stuk beperkter dan wanneer men in dezelfde tijdzone werkt.

3. Afstand in cultuur. Cultuurverschillen op nationaal of organisatieniveau maken communiceren moeilijker. Zo heeft de afstand tussen medewerker en baas, ofwel de mate van ongelijkheid in een cultuur - grote invloed op de manier waarop teamleden met elkaar omgaan. Daar waar cultuurverschillen wel expliciet worden geadresseerd, is de kans op succes hoger.

4. Afstand tussen organisaties. Verschillen tussen organisaties kunnen leiden tot problemen op het gebied van samenwerking in een project. Er zijn verschillende soorten verschillen mogelijk: bijvoorbeeld verschillen in organisatievorm, maar ook verschillen in IT-processen of de mate van professionaliteit daarvan.

5. Afstand tussen belanghebbenden. Werk is een samenspel tussen diverse partijen. Elk van de partijen heeft zijn eigen belangen, doelstellingen en visie op succes.

Al deze afstanden hebben een negatief effect op de communicatie in een team (Carmel \& Agarwal, 2001). Er wordt minder informatie uitgewisseld over de stand van zaken, er is nauwelijks informeel contact en er ontstaat slechts een band tussen de teamleden op de afzonderlijke locaties. Wanneer door deze beperkte band tussen locaties een aantal problemen ontstaat, zorgt dit voor wantrouwen jegens elkaar. Er wordt alleen contact opgenomen wanneer een probleem ver gevorderd is en 


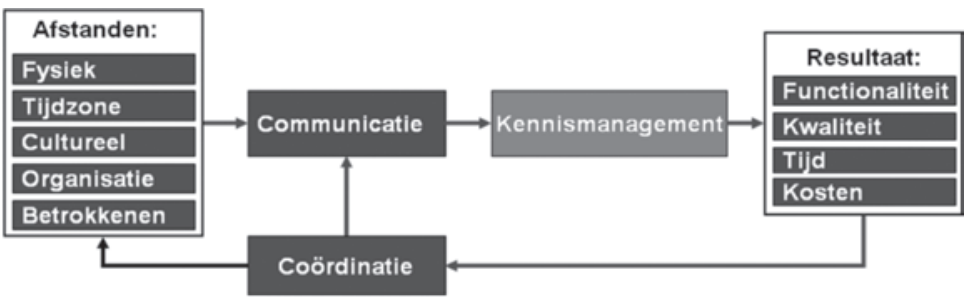

Figuur 8 De invloed op succes in wereldwijd verspreid werk (Fabriek et al, 2007)

direct contact de enige oplossing lijkt (Layman, Williams, Damian and Bures, 2006). Er is minder communicatie waardoor minder kennis over het werk uitgewisseld wordt.

Als de afstand tussen twee teams, één onshore en één offshore, groot is, bestaat het risico van "werk over de muur gooien". Fabriek et al (2007) beschrijven hoe dat in sommige gevallen ertoe leidde dat men na de voorbereidingen in Nederland het ontwerp 'over de muur gooide'. India moest het vervolgens maar maken zonder dat er veel communicatie was. In andere gevallen was de afstand tussen de teamleden klein geworden door informeel contact. Dit leidde tot meer communicatie.

Communicatie is, zoals eerder reeds gesteld, essentieel in het delen van kennis. Doordat communicatie negatief beïnvloed wordt door afstand, wordt in een offshore project slechts beperkt kennis uitgewisseld. Dit leidt ertoe dat bepaalde kennis verloren gaat of verkeerd wordt overgedragen aan andere teamleden. In de praktijk is dit vaak te zien: een team in India bouwt volgens specificaties, maar in Nederland blijkt dat bepaalde specificaties niet goed begrepen zijn. Dit wordt niet veroorzaakt door de kwaliteit van de Indiërs, maar door de gebrekkige kennisdeling ten gevolg van de beperkte communicatie (Cramton, 2001).

Uiteindelijk beïnvloedt de gebrekkige kennisdeling het resultaat van het werk. Het wordt lastiger om gestelde doelen te bereiken, die in generieke zin meestal de volgende zijn:

- De gevraagde functionaliteit moet geleverd worden.

- De kwaliteit van het resultaat moet minimaal op het niveau zijn dat is afgesproken.

- Het werk moet op tijd afgerond zijn.

- De totale kosten moeten de begroting niet te boven gaan. 
Sommige organisaties besluiten om werk over de wereld te verspreiden met als hoofddoel de kosten te verlagen. Vaak leidt dit inderdaad tot lagere kosten, maar er wordt ingeleverd op doorlooptijd en kwaliteit. In dat geval is er geen sprake van succes.

We kunnen een aantal coördinatiemiddelen toepassen die de communicatie bevorderen (Van den Brand \& Harmsen, 2005). Er zijn twee wegen waarlangs dit kan gebeuren.

Allereerst kan de organisatie besluiten om bepaalde afstanden te verkleinen (Carmel \& Agarwal, 2001). Voorbeelden hiervan zijn:

1. Regelmatige bezoeken tussen de verschillende partijen helpt om de fysieke afstand kleiner te maken.

2. Het toepassen van technologische communicatiemiddelen zoals videoconferencing, of chatting. Hierdoor wordt de impact van de fysieke afstand op de communicatie minder groot.

3. Het afstemmen van werktijden in verschillende locaties van het project. Hierdoor zijn tijdsverschillen minder storend.

4. Cultuurtrainingen helpen om elkaars achtergronden en beweegredenen te begrijpen. Dit verkleint de culturele afstand.

5. Taalcursussen helpen om de voertaal in het project af te stemmen en dichter tot elkaar te komen.

6. Het in contact brengen van de offshore medewerkers en de opdrachtgever helpt om de belangen meer op één lijn te krijgen. Dit helpt om de afstand tussen belanghebbenden te verkleinen.

7. Er voor zorgen dat er één organisatie in de twee betrokken landen is. Dit helpt om de cultuurverschillen en de afstanden tussen belangen zo klein mogelijk te houden.

Naast het verkleinen van de afstanden zijn er ook maatregelen die de communicatie direct beïnvloeden (Sabherwal, 2003). Een paar voorbeelden:

1. Het overbrengen van een 'onshore coördinator'. Deze persoon kan de communicatie tussen on- en offshore verbeteren.

2. Het samenstellen van een eigen projectmethode. Wanneer dit samen gedaan wordt voelen de partijen op beide locaties zich betrokken bij het proces. Dit zorgt voor actieve deelname van beide zijden en dus voor meer communicatie.

3. Verantwoordelijkheden duidelijk verdelen over de verschillende partijen. Wanneer mensen zich verantwoordelijk voelen, nemen ze meer initiatief om contact met anderen op te nemen. 
4. Duidelijke communicatiekanalen benoemen en afspreken. Door te bepalen wie er met wie communiceert, wordt de communicatie duidelijker en efficiënter.

5. Werkafspraken maken over escalaties en beslissingsbevoegdheden. Hierdoor is duidelijk hoe er met problemen omgegaan dient te worden.

6. Inzicht geven in planning en voortgang van de partijen. Door de verschillende partijen inzicht te geven in de overall planning en de planningen van de verschillende partijen wordt duidelijk wie wat wanneer doet.

Uit het model volgt dat we een aantal stuurwielen hebben om aan te draaien. Het centrale wiel is communicatie. Dit is geen wiel waar aan gedraaid wordt, maar in beweging wordt gezet door de twee andere wielen 'afstand' en 'coördinatie'. Wanneer we de afstand verkleinen en extra coördinatiemiddelen toepassen leidt dat tot betere communicatie en daardoor tot betere resultaten. Het lijkt simpel: draai even aan de stuurwielen 'afstand' en 'coördinatie'.

Zo simpel is het helaas niet. In (Fabriek et al, 2007) worden 4 cases behandeld waarin aan deze wielen is gedraaid, maar in sommige cases leidde dit niet tot succes. In de praktijk kost het draaien aan de wielen namelijk geld en tijd. Bij teams die zich in hetzelfde land bevinden is het draaien aan de wielen relatief goedkoop. Bij teams die samenwerken vanuit twee of meer landen ligt dat anders. Maatregelen om de wielen in beweging te zetten vormen additionele kosten, die opgebracht moeten worden door de meeropbrengsten van offshoring. Een organisatie moet zich daarom afvragen of deze additionele kosten voor het succesvol maken van offshoring opwegen tegen de opbrengsten ervan. Regelmatige bezoekjes van offshore personeel aan Nederland leiden zeker tot betere communicatie, maar vliegtickets zijn prijzig en de verblijfskosten zijn hoog. De kunst is dus om de additionele kosten ter garantie van succes af te stemmen op de mogelijke voordelen van wereldwijd verspreid werk.

Dat brengt mij op mijn onderzoeksagenda. In het eerder genoemde model breng ik kennismanagement in verband met afstand, communicatie, coördinatie en resultaat. Hierbij zijn afstand, communicatie en coördinatie de knoppen waar we aan draaien - kennismanagement en resultaat volgen hier uit. Uiteindelijk gaat het natuurlijk om het laatste : hoe zorg 
je ervoor dat je met beperkte middelen en tegen de laagste kosten een zo goed mogelijk resultaat boekt? Kennismanagement van wereldwijd verspreid werk is hiervoor ook maar een middel. In mijn onderzoek ga ik me richten op twee hoofdonderwerpen:

1. De drie stuurparameters: afstand, communicatie en coördinatie.

2. De balans tussen enerzijds de parameters afstand, communicatie en coördinatie onderling, en anderzijds tussen de drie parameters en het resultaat van het werk.

Hieronder ga ik wat dieper in op die twee hoofdonderwerpen.

Allereerst de drie wielen afstand, communicatie en coördinatie. Die parameters kunnen nauwelijks los van elkaarworden gezien. Zoals eerder al betoogd, kunnen betere communicatie en coördinatie afstanden verkleinen. Kleinere afstanden leiden dan weer tot betere communicatie en dat leidt tot betere kennisuitwisseling en kennismanagement.

Ten aanzien van coördinatie bepleit ik een simpel en situationeel model - het heeft geen zin om te komen met dikke handboeken vol regels en procedures om werk te coördineren, omdat ze niet aansluiten op de praktijk van alledag. Ook een zwaar besturingsmodel werkt niet - dat is te duur en vergroot de afstanden en daarmee de kans op succesvolle communicatie. Ik ga me daarom richten op 'lichtere' en situationele coördinatiemechanismen. Ik ben altijd een sterk voorstander geweest van de teamgedachte: er is één team met een gemeenschappelijk doel. Het maakt niet uit waar de individuele leden van dat team zich bevinden, want het doel heiligt alle middelen en de missie van het team is ondergeschikt aan de plaats van de individuele teamleden. Capgemini brengt dit paradigma succesvol in de praktijk onder de noemer "One Team" en het is interessant om dit concept nader te onderzoeken en te verbeteren. Daarnaast bepleit ik het gebruik van situationele methoden, in combinatie met een gemeenschappelijk begrippenkader.

Mijn stelling is dat beide coördinatiemechanismen, "One Team" en situationele methode, afstanden verkleinen en communicatie verbeteren. In het kader van communicatieverbetering zijn er ook allerlei technische hulpmiddelen en processen. Langzamerhand is bijvoorbeeld het middel videoconferencing volwassen geworden. In een organisatie waar veel wereldwijd verspreid werk plaatsvindt is het vergaderen via een videoverbinding heel normaal geworden. Geholpen 


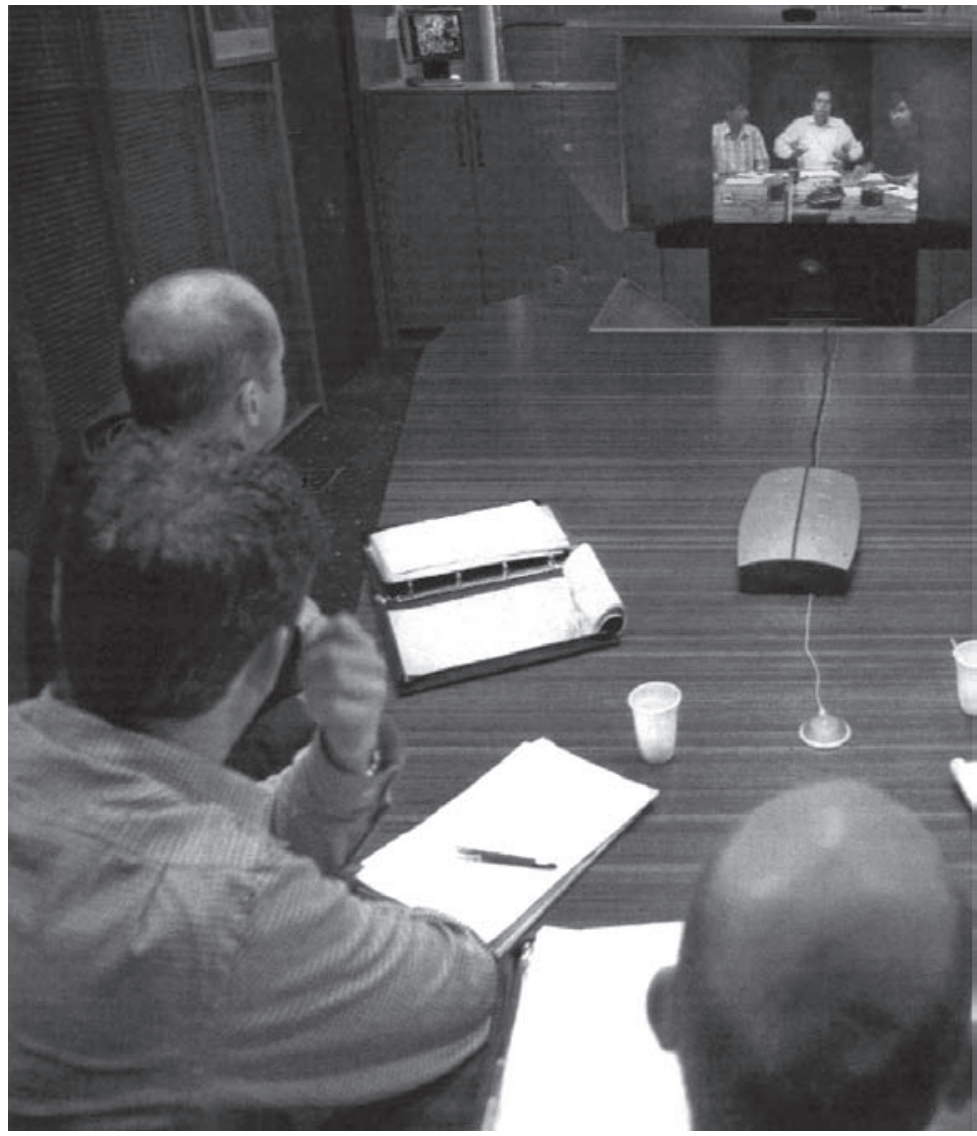

Figuur 9 Voorbeeld van een videoconference-faciliteit: de cPort

door breedbandverbinding en geavanceerde semi 3D apparatuur die bovendien relatief betaalbaar is geworden, zijn vergaderingen en soms zelfs workshops op afstand echt haalbaar. Dit heeft niet alleen een prettig effect op kennismanagement, maar ook op het milieu: ik heb bijvoorbeeld al heel wat autoritjes tussen Zuid-Limburg en Utrecht uitgespaard vanwege onze fraaie videoconferentie_facili-tei-ten.

Ook de op de 'Accelerated Solutions Enviroment' (ASE) gebaseerde workshops zijn voorbeelden van manieren om kennismanagement van wereldwijd verspreid werk te verbeteren (van den Berg et al, 2004). Dat soort workshops zijn echte snelkookpannen: in één of enkele dagen 
worden alle belanghebbenden bij elkaar gebracht om kennis uit te wisselen. Op die manier worden processen van maanden verkort tot dagen, met alle voordelen van dien. Er is echter nog relatief weinig onderzoek gedaan naar de effecten van dit soort middelen op het verkorten van afstanden en het verbeteren van kennismanagement.

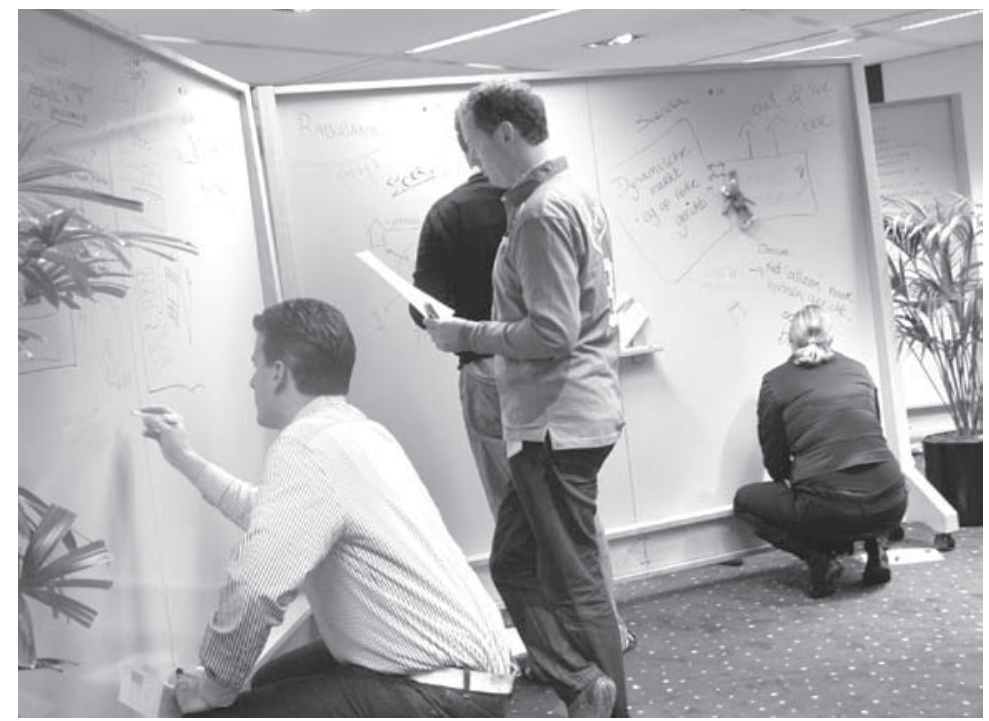

Figuur 10 Workshop in een Accelerated Solutions Environment

Het stuurwiel 'afstand' is een hele interessante. Sommige afstanden liggen echt buiten mijn bereik. Het verkleinen van fysieke afstanden en afstanden tussen tijdzones lijken mij echt heel interessant om te onderzoeken, maar ik acht me daartoe ongeschikt. Afstanden tussen culturen komen wel aan bod in mijn onderzoek, maar het onderwerp is al uitgebreid onderzocht door coryfeeën als Hofstede, en ook daarmee wil en kan ik mij niet meten. Blijven over: de afstanden tussen organisaties en die tussen betrokkenen. Dat zijn de afstanden die ik in mijn consultancywerk veel ben tegengekomen. Laatstgenoemde afstand heeft nog een behoorlijke relatie met communicatie en daarmee met de hulpmiddelen die daarvoor kunnen worden ingezet. De ASE, bijvoorbeeld, is een instrument om afstanden tussen betrokkenen te verkleinen. Afstanden tussen organisaties hebben veel te maken met 
de volwassenheid van mensen, middelen en processen. Mijn stelling is, dat als twee organisaties die qua volwassenheid veel van elkaar verschillen kennis met elkaar uitwisselen, dit op zijn minst ineffectief is (meestal mislukt het). Om kennisuitwisseling te verbeteren, zal er iets aan de volwassenheid van minimaal één van beide organisaties moeten worden gedaan. Organisatie is in dit verband een generiek begrip het kan dus ook van toepassing zijn op afdelingen of zelfs informele structuren in hetzelfde bedrijf. Het meest duidelijk zien we dat, als een bedrijf, de klant, besluit een deel van zijn activiteiten uit te besteden aan een andere organisatie, de leverancier. Als vergeten wordt om de volwassenheid van het "achterblijvende" deel van de klantorganisatie op peil te brengen, is de uitbesteding gedoemd te mislukken. Wat gebeurt er namelijk? Deze retained organization zal de leverancier moeten gaan besturen. Er zullen vragen moeten worden gesteld: "Beste leverancier, wilt u mij dienst X leveren?". Als een retained organization niet in staat is om zelfs al maar de vraag te stellen (en dat gebeurt in de praktijk maar al te vaak), laat staan te controleren of de dienst die geleverd wordt die de vraag beantwoordt, dan schiet uitbesteding zijn doel voorbij.

Het tweede hoofdonderwerp betreft de balans tussen de drie genoemde parameters afstand, communicatie en coördinatie, het resultaat van het wereldwijd verspreide werk en het kennismanagement. Dat resultaat kan benoemd worden in termen van de eerder beschreven onderdelen functionaliteit, kwaliteit, tijd en kosten, maar kan ook in een nog breder verband worden beschouwd, bijvoorbeeld in termen van ecologische voetafdruk, of überhaupt de impact die het resultaat heeft op zijn omgeving.

Een poging om de balans tussen afstand, communicatie en coördinatie te objectiveren kan naar mijn idee alleen maar succesvol zijn, als je de afzonderlijke onderdelen van die balans kunt kwantificeren in termen van geld. Met andere woorden: wat zijn de kosten en wat zijn de opbrengsten van het draaien aan de afzonderlijke knoppen, wat is de business case? Wat gebeurt er bijvoorbeeld met de kosten en de opbrengsten als je de fysieke afstand tussen twee werklocaties vergroot? Als je je werk naar India verplaatst, kun je verwachten dat de loonkosten omlaag gaan, maar de kosten van reizen en van coördinatie en communicatie zullen stijgen. Wellicht zal echter de productiviteit ook veranderen, waardoor de opbrengsten lager of hoger worden. Interessante vragen in dit verband zijn onder andere: Over welke periode 
beschouw je dan die kosten en opbrengsten? Zijn de onderdelen wel uit te drukken in financiële termen? Hoe kun je kennis uitdrukken in termen van geld? Welke financiële indicatoren gebruik je? Dit soort vragen wil ik in samenwerking met de faculteit Economische Wetenschappen en Bedrijfskunde beantwoorden, bijvoorbeeld als het gaat om toepassing van concepten als Activity Based Costing en de Balanced Scorecard (Kaplan, 1996).

Samenvattend: mijn leerstoel gaat zich richten op het managen van kennis in een wereldwijd verspreid netwerk. Ik zie kennismanagement als een resultante van de parameters afstand, communicatie en coördinatie, en ik ga me dan ook bezighouden met het onderzoeken van die parameters - ik noem ze "stuurwielen"- om kennismanagement van wereldwijd verspreid werk te onderzoeken en hopelijk te optimaliseren. Daarnaast ga ik specifiek kijken naar de financiële balans tussen de drie eerder genoemde "knoppen" en het resultaat van het wereldwijd verspreide werk. 


\section{Dankwoord}

Het werken aan zo'n inaugurele rede is ook een vorm van kennismanagement. Je eigen kennis en visie combineer je met je ervaringen in de praktijk en de kennis van anderen, en zo hoop je tot een synthese te komen en een product op te leveren dat de moeite waard is. Zoals ik al in mijn rede heb benadrukt, is het team-aspect van kennismanagement enorm belangrijk. Ik geloof ontzettend in de kracht van het team. Ik heb het geluk gehad dat ik in mijn leven onderdeel ben geweest, of nog ben, van een aantal sterke teams, teams die mij direct of indirect enorm hebben geholpen en dus ook direct of indirect een wezenlijke bijdrage hebben geleverd aan deze rede. Ik zal niet iedereen kunnen noemen, dus ik beperk me tot de allerbelangrijkste mensen die met mij een team hebben gevormd en mij hebben gestimuleerd en geholpen. Ik doe dat in omgekeerd chronologische volgorde.

Allereerst bedank ik de rector en het College van Bestuurvan de Universiteit Maastricht en de decaan van de faculteit der Algemene Wetenschappen voor het instellen van deze leerstoel.

Ik wil Capgemini bedanken, en specifiek Kaeso de Jager en Wil van Hamersveld, die mij in staat stellen deze leerstoel voor één dag in de week te bekleden. Ook de volgende collega's en ex-collega's van Capgemini en Ernst \& Young wil ik expliciet heel hartelijk danken voor de nauwe samenwerking de afgelopen jaren: Mischa van den Brand, Michiel Borgers, Maickel Sweekhorst, Peter Groenendaal, Suzanne Langen en Leo Diepstraten. Ik ben me ervan bewust dat ik nu tientallen collega's uit bijvoorbeeld Heerlen, Utrecht en andere plaatsen waar Capgemini zich bevindt niet noem, maar dat maakt mijn dankbaarheid jegens hen er niet minder op.

Jaap van den Herik is de hoogleraar met wie ik begin 2006 een oriënterend gesprek had en die een cruciale rol heeft gespeeld in mijn benoeming aan de Universiteit Maastricht. Ik heb hem leren kennen als een uiterst scherpzinnig en sympathiek mens, een gedreven topwetenschapper die op een leeftijd waarop anderen met pensioen gaan, nog een hoogstaand wetenschappelijk instituut, het Tilburg Institute for Creative Computing, heeft opgericht. Ik wens hem alle succes hiermee. Dat geldt ook voor zijn collega, professor Eric Postma - ook hij is een hoogleraar die je gevoeglijk als voorbeeldfiguur mag beschouwen. Mijn dank voor jullie beider doorzettingsvermogen is erg groot! 
Jan Willem Pauw heeft een aantal jaar geleden, ik meen dat het 2004 of 2005 was, in een beoordelingsgesprek op een vrij scherpe manier aangegeven dat het allemaal wel erg makkelijk ging en dat ik toe was aan een uitdaging van een andere orde. "Waarom word je geen hoogleraar?", vroeg hij toen. Destijds verklaarde ik hem in eerste instantie voor gek , want ik wist nog van de tijd dat ik AlO was hoe moeilijk het is om in dat ambt benoemd te worden. Maar ik ben blij dat hij mij zo geprikkeld heeft - niet alleen op dit vlak, maar ook jarenlang als mentor in het consultancywerk.

Een persoon die vanaf 1990, toen ik nog student was aan wat toen de Katholieke Universiteit Nijmegen heette (nu de Radbouduniversiteit), een hele belangrijke rol heeft gespeeld in mijn leven is professor Sjaak Brinkkemper, thans hoogleraar aan de Universiteit Utrecht. Ik heb in de afgelopen 19 jaar veel met hem samengewerkt - eerst als studentassistent, toen bijna 4 jaar als AlO op de Universiteit Twente, daarna als consultant en practicemanager. Hij was het die Jaap van den Herik en mij met elkaar in contact bracht en ik kan dus gerust stellen, dat hij, samen met Jaap, aan de wieg van mijn leerstoel heeft gestaan.

Ik heb het in mijn oratie gehad over teams, onder andere het "One Team Model". Teams komen en gaan. Met alle mensen die ik hiervoor heb genoemd heb ik, soms wat langer en soms wat korter, in een team samengewerkt. Het team waarvan ik het langst deel uitmaak is toch wel mijn naaste familie. Het laatste dankwoord gaat naar hen uit: dank voor al jullie liefde en steun gedurende de eerste 40 jaar van mijn leven, of een groot deel daarvan. Mireille en ik waren jarenlang een winning team, waar ik met veel liefde en dankbaarheid op terugkijk. Dankjewel Mireille! Er zijn helaas ook al te veel mensen in mijn familie die dit moment niet meer kunnen meemaken - ik doel dan vooral op mijn opa's en oma's, die mij altijd met veel liefde hebben omringd en die nu ongetwijfeld erg trots zouden zijn. Ik ben ervan overtuigd dat die liefde mij gevormd heeft tot wat ik nu ben. Ik dank Con en Koos, en Denise, Cor en Tom - ook hun vriendschap, gezelligheid en steun heb ik altijd erg gewaardeerd. En bovenal dank ik mijn ouders, Trudy en Gert-Jan, voor alles wat ze mij hebben gegeven en waarmee ze mij hebben gesteund en geïnspireerd.

Ik heb gezegd. 


\section{Referenties}

Ackoff, R. L., "From Data to Wisdom", Journal of Applies Systems Analysis, Volume 16, p 3-9, 1989 .

Agarwal, N., Rathod, U., Defining 'success' for software projects: An exploratory revelation. International journal of project management, 24, 358-370, 2006.

Berg, B. van den, Ribbers, F., Reek, L., Meijs, M., Heijnen, M., van Laanen, M., Colenbrander, R., Redeker, S., Impact - De kracht van groepsdialoog bij succesvolle organisatieverandering, van Gorcum, 2004

Brand, M. van den, Harmsen, F., Doet de methode het ook in India? Informatie, oktober 2005.

Brinkkemper, S., Method Engineering: Engineering of Information Systems Development Methods and Tools, Journal of Systems and Software, Vol. 38, 1996.

Carmel, E., Agarwal, N., Tactical approaches for alleviating distance in global software development. IEEE Software, maart/april 2001.

Cavusgil, S.T., Yaprak, A., Yeoh, P.L., A decision-making framework for global sourcing. International Business Review, Vol. 2, Issue 2, 143-156, 1993.

Conchuir, E.O., Holmstrom, H., Agerfalk, P.J. \& Fitzgerald, B., Exploring the assumed benefits of global software development. IEEE International conference on global software engineering, 2006.

Cramton, C.D., The mutual knowledge problem and its consequences for dispersed collaboration. Organization science, 21(3), 346-371, 2001.

Currie, W., Willcocks, L., New Strategies in IT Outsourcing: Trends and Global Best Practices. Business Intelligence, London, 1997.

Edmondson, A.C., Winslow, A.B., Bohmer, R.M.J., Pisano, G.P., Learning How and Learning What: Effects of Tacit and Codified Knowledge on Performance Improvement Following Technology Adoption, Decision Sciences, Spring 2003.

Fabriek, M., van den Brand, M., Harmsen, F., Brinkkemper, S., De juiste balans voor succesvol offshoren. Informatie, april 2007.

Falkenberg, E.D., Hesse, W., Lindgren, P., Nilsson, B.E., Han Oei, J.L., Rolland, C., Stamper, R.K., Van Assche, F.J.M., Verrijn-Stuart, A.A., Voss, K. (Eds.), FRISCO A Framework of Information System Concepts (Eds.). International Federation for Information Processing, 1998. (ftp://ftp.leidenuniv.nl/pub/rul/fri-full.zip)

Friedman, T.L., The world is flat: a brief history of the globalized world in the 21st century. London, Penguin Books, 2005. 
Gumm, D.C., Distribution dimensions in software development projects: a taxonomy. IEEE Software, september/oktober 2006.

Harmsen, F., Brinkkemper, S., Oei, H., Situational Method Engineering for Information System Projects. In: Olle, T.W., and A.A. Verrijn Stuart (Eds.), Methods and Associated Tools for the Information Systems Life Cycle, Proceedings of the IFIP WG8.1 Working Conference CRIS'94, North-Holland, pp. 169-194, Amsterdam, 1994.

Harmsen, F., Lubbers, I., Wijers, G., Success-driven Selection of Fragments for Situational Methods: The S3 model. In: Pohl, K., and P. Peters (Eds.), Proceedings of the Second International Workshop on Requirements Engineering: Foundations of Software Quality (REFSO'95), Aachener Beiträge zur Informatik, Band 13, pp. 104-115, Aachen, 1995.

Harmsen, A.F., Situational Method Engineering. Proefschrift Universiteit Twente, januari 1997.

Harmsen, F., Kleijnen, J., Invoering van DSDM, Informatie, maart 2003.

Harmsen, F., van den Brand, M., Strategic Sourcing: criteria, risico's en maatregelen, Jaarboek IT Beheer en informatiebeveiliging 2006 (red. F. Noë), Academic Service, 2006.

Herik, H.J., Postma, E.O., Veertig jaar, zes doorbraken, afscheidscollege Universiteit Maastricht, 16 oktober 2008.

Hofstede, G., Hofstede G.J., Cultures and Organizations - Software of the Mind (revised and expanded edition). McGraw-Hill, 2006.

Jager, C.J., Vos, S., Borgers, M., Harmsen, F., Brinkkemper, S. \& Van de Wijngaert, L.. Controlling risk prior to offshore application development. In: Proceedings of the Global Sourcing Workshop, Val d'Isère, 2008 (http://www.globalsourcing.org.uk/ papers.htm).

Kaplan, R.S., Norton, D.P., The Balanced Scorecard:Translating Strategy into Action, Harvard Business School Press, Boston, Ma., 1996.

Layman, L., Williams, L., Damian, D., \& Bures, H., Essential communication practices for extreme programming in a software development team. Information and software technology, 48, 781-794, 2006.

Looff, L. de, A Model for Information Systems Outsourcing Decision Making. Doctoral Dissertation, Technische Universiteit Delft, 1996.

Man, A.P. de, Van der Zee, H., Geurts, D., Succesvol samenwerken: over strategische samenwerking in het netwerktijdperk. Financial Times/Prentice Hall, Amsterdam, 2001.

Mol, M., Outsourcing, supplier relations and internationalisation: Global sourcing strategy as a Chinese puzzle. Doctoral Dissertation, Erasmus Universiteit Rotterdam, 2001. 
Polanyi, M., Personal knowledge: towards a post-critical philosophy. Chicago, IL: University of Chicago Press, 1958.

Sabherwal, R., The evolution of coordination in outsourced software development projects: a comparison of client and vendor perspectives. Information and organization, 13, 153-202, 2003.

Schrijver, M., Wereldwonder in de zee. In: De Volkskrant, 16 augustus 2008.

Stamper, R.K., Measur: Method for Eliciting, Analyzing and Specifying User Requirements. In: Olle, T.W., A.A. Verrijn Stuart (Eds.), Computerized Assistance during the Information Systems Life Cycle, North-Holland, Amsterdam, 1988.

Steenbeek, W., Van de Wijngaert, L., Brinkkemper, S., Van den Brand, M., Harmsen, F., Sourcing Decision-Making: Elicitating Consultancy Knowledge using Policy Capturing, Proceedings European Conference on Information Systems, Regensburg, 2005 .

Steenbeek, W., Van den Brand, M., Harmsen, F., Sourcing in 23 definities, IT beheer jaarboek 2004/2005 (red. F. Noë), Academic Service, 2004.

Stol, H.R., A Framework for Evidence-Based Policy Making Using IT. TiCC dissertation series no.3, 2009 .

Polanyi, M., The tacit dimension. Garden City, NY: Doubleday, 1966

Sole, D., Edmondson, A.. Situated knowledge and learning in dispersed teams. British Journal of Management, 13(Special Issue), S17-S34, 2002.

Teece, D. J., Technology transfer by multinational firms: The resource cost of transferring technological know-how. Economic Journal, 87(346), 242-261, 1977.

Verhoef, C., Quantitative Aspects of Outsourcing Deals, Vrije Universiteit van Amsterdam, 2003.

Vosburgh, K. G., Newbower, R. S., Moore's law, disruptive technologies, and the clinician. In J. D. Westwood, H. M. Huffman, G. T. Mogel, R. A. Robb, \& D. Stredney (Eds.), Medicine meets virtual reality. Amsterdam: IOS Press, 8-13, 2000.

Ward, J., Peppard, J., Strategic Planning for Information Systems. Wiley, Chichester, 2002.

Wennberg, J. E., Physician uncertainty, specialty ideology, and a second opinion prior to tonsillectomy. Pediatrics, 59(6), 952, 1977.

Yang, C., Huang, J.B., A decision model for IS outsourcing. International Journal of Information Management, Vol. 20, Issue 3, 225-239, 2000. 
